CARLA ITABORAI VIEIRA

\title{
BRASIL E VENEZUELA: SISTEMA BANCÁRIO O QUE LEVOU O BRASIL A INVESTIR NO PAÍS VIZINHO
}

Trabalho de Conclusão de Curso de Relações Internacionais para a Universidade de Brasília, apresentado como requisito parcial à obtenção do título de Especialista em Relações Internacionais. 
CARLA ITABORAI VIEIRA

\title{
BRASIL E VENEZUELA: SISTEMA BANCÁRIO O QUE LEVOU O BRASIL A INVESTIR NO PAÍS VIZINHO
}

\begin{abstract}
Trabalho de Conclusão de Curso de Relações Internacionais para a Universidade de Brasília, apresentado como requisito parcial à obtenção do título de Especialista em Relações Internacionais.
\end{abstract}

Orientadora:

Prof. ${ }^{a}$ Ana Flávia Barros Platiau 
FICHA CATALOGRÁFICA

Vieira, Carla Itaboraí
Brasil e Venezuela: Sistema Bancário - O que levou o Brasil a investir no país vizinho /
Carla Itaboraí Vieira; Orientadora: Ana Flávia Barros Platiau. Brasília, 2010. 53p.
Trabalho de Conclusão de Curso. Instituto de Relações Internacionais / Universidade de
Brasília. Curso de Especialização em Relações Internacionais.
1.Brasil: Sistema bancário brasileiro; programas sociais do governo e de financiamento
habitacional; a participação brasileira no Mercosul. 2. Venezuela: Sistema bancário
venezuelano; programas sociais do governo e de financiamento habitacional; a
participação venezuelana no Mercosul. 3. A relação entre Brasil e Venezuela: política
externa; Mercosul; sistema bancário; a Caixa Econômica Federal na Venezuela.




\section{AGRADECIMENTOS}

Agradeço a meus pais pelo apoio constante.

À profesora Ana Flávia pela ótima orientação.

À Celi pelo excelente atendimento na secretaria e pelo carinho.

Aos colegas de classe pelo companheirismo. 


\section{RESUMO}

Em outubro de 2009 o Senado Brasileiro aprovou a adesão da Venezuela ao Mercosul. Essa aprovação gerou controvérsias acerca dos interesses brasileiros nessa nova parceira. No início deste mesmo ano a Caixa Econômica Federal, a qual é um banco público, inaugurou as instalações de um escritório internacional naquele país. Com a adesão de um novo país no bloco econômico este retomaria suas forças, já que o mesmo estava enfraquecido? O governo brasileiro tem interesse na adesão desse país no Mercosul? Por que a Caixa Econômica investiu na Venezuela? A abertura do escritório internacional da Caixa teria facilitado a entrada da Venezuela no Mercosul?

Para responder estes questionamentos utilizamos como técnica a pesquisa bibliográfica, bem como a análise de uma entrevista realizada com o gerente do escritório de representação internacional da Caixa Econômica localizado na Venezuela. Após análise dos dados, concluimos que apesar de visar negócios no âmbito do Mecorsul, a abertura do escritório internacional da Caixa Econômica na Venezuela não influenciou na aceitação da entrada do país vizinho pelo Senado Federal Brasileiro no bloco econômico. A parceria estabelecida entre a Caixa e o governo da Venezuela é lucrativa para todos, pois haverá a urbanização de favelas, a capacitação profissional e a geração de emprego e renda, além de assistência técnica e desenvolvimento de fundos para financiamento habitacional e de infraestrutura na Venezuela. A Caixa Econômica será um instrumento de envio de remessas para o Brasil, bem como facilitará negócios de pequenas empresas que atuam no Mercosul. Um novo membro trará novos ares e, consequentemente, benefícios para o mesmo. A entrada da Venezuela no Mercosul é de interesse do Brasil pois esse país tem a política externa voltada para a América do Sul, assim como o Brasil, além de ser um vasto mercado consumidor de produtos brasileiros e um grande fornecedor de petróleo. 


\begin{abstract}
In October 2009, the Brazilian Senate approved the ingress of Venezuela in Mercosul. This approval brought about some controversies about the Brazilian interests in that partnership. In the beginning of the same year, Caixa Econômica Federal, a public bank, inaugurated an international bureau in that country. With the ingress of a new country in this economic block, would Mercosul be strong again, since it was debilitated? Does the Brazilian government have interests in Venezuela's participation in the Mercosul? Why has Caixa Econômica invested in Venezuela? Did the inauguration of the Caixa's International Bureau facilitate Venezuela's participation in Mercosul?

In order to answer these questions, the writer conducted a literature review as well as an analysis of an interview with the manager of Caixa Econômica Federal's international bureau in Venezuela. After the data analysis, the author concluded that although Caixa Econômica seeks to negotiate with companies which are established in Mercosul, the Caixa Econômica's international bureau inauguration in Venezuela did not influence this country's acceptance in the economic block by the Brazilian Senate. The partnership established between Caixa and the Venezuelan government is lucrative for all, since there will be urbanization of the slums, professional development, and employment and income creation. Besides that, Caixa will offer tecnical assistance and the development of funds for housing financing and infrastructure in Venezuela. In addition, Caixa Econômica will be an instrument used to send money to Brazil. It will also facilitate the business of the small companies that are part of Mercosul. A new member may bring benefits to the block. The ingress of Venezuela in Mercosul interests Brazil because the Venezuelan foreign policies are focused on South America as well as on Brazil. Also, this country is an important consumer of Brazilian products and a large oil supplier.
\end{abstract}




\section{SUMÁRIO}

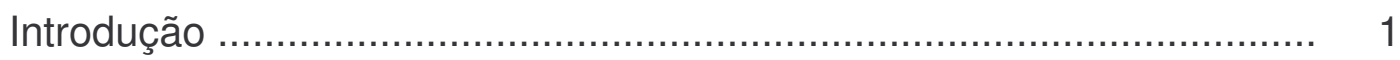

Capítulo 1 - Brasil ........................................................................ 3

1.1 Da criação do sistema bancário brasileiro aos dias atuais .............. 3

1.2 A função social do banco público brasileiro - A Caixa Econômica Federal .................................................................................... 9

1.3 O programa de financiamento habitacional brasileiro .................. 12

1.3.1 O programa Minha Casa Minha Vida .......................................... 13

1.3.2 O sistema de financiamento habitacional .................................... 13

1.4 O Brasil e o Mercosul ................................................................. 15

Capítulo 2 - Venezuela ........................................................... 17

2.1 O sistema bancário venezuelano ................................................... 17

2.1.1 O Conselho Nacional dos Bancos .......................................... 19

2.1.2 A Superintendência dos Bancos e Outras Instituições Financeiras ........................................................................ 20

2.1.3 O Fundo de Garantia de Depósito e Proteção Bancária (FOGADE) ........................................................................ 23

2.2 Os programas sociais do governo venezuelano ............................. 25

2.2.1 Programas sociais realizados com o excedente da renda da PDVA

2.2.2 O Banco Del Pueblo Soberano .................................................... $\quad 26$

2.3 Programa de Financiamento Habitacional Venezuelano ................. 27

2.4 A Venezuela e o Mercosul ........................................................ 28

Capítulo 3 - A relaçãp entre Brasil e Venezuela ................................. 31

3.1 Política externa voltada para o Mercosul ...................................... 31

3.2 O sistema bancário do Brasil e da Venezuela ................................ 36

3.3 Análise da entrevista realizada com o gerente do escritório internacional da Caixa Econômica Federal na Venezuela .................... 39

3.3.1 Objetivo da Caixa em abrir o escritório internacional na Venezuela

3.3.2 Benefícios para Venezuela devido à implantação do escritório da Caixa Econômica

3.3.3 A abertura do escritório internacional da Caixa e a participação da Venezuela no Mercosul .............................................................. 41

3.3.4 A Venezuela e o Mercosul ....................................................... 42

3.3.5 Política internacional adotada pelo governo Lula ....................... 42

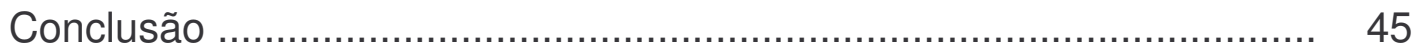

Referências Bibliográficas ........................................................ 48

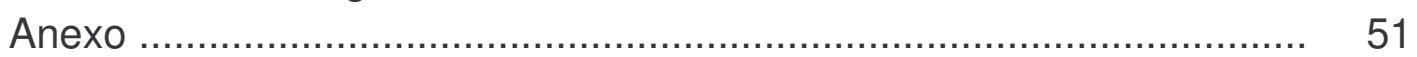




\section{INTRODUÇÃO}

Após muitos entraves, em outubro de 2009 o Senado Brasileiro aprovou a adesão da Venezuela ao Mercosul. Essa aprovação gerou controvérsias acerca dos interesses brasileiros nessa nova parceira. Não se concluiu, tampouco, se a entrada desse novo membro no Mercosul traria mais vantagens ou desvantagens para o bloco.

No início deste mesmo ano a Caixa Econômica Federal, a qual é um banco público, inaugurou as instalações de um escritório internacional na Venezuela. Sabemos que os bancos são instituições de caráter universal. Eles realizam diversas operações como aplicações, empréstimos, pagamentos de boletos, concessão de crédito habitacional, além de efetuarem transações de programas sociais. Essas diversas operações são realizadas não somente em um único país, mas podem envolver a rede bancária do mundo globalizado.

Esta pesquisa se deve à recente aprovação da entrada da Venezuela no Mercosul pelo Brasil e à discussão envolvendo esse fato. $O$ bloco econômico em questão havia enfraquecido ao longo do tempo. Com a adesão de um novo país este retomaria suas forças?

É notado que o Brasil vem estreitando as relações com a Venezuela. Qual seria o interesse do governo brasileiro na adesão desse país ao Mercosul? Por que a Caixa Econômica investiu na Venezuela? A abertura do escritório internacional da Caixa teria facilitado a entrada da Venezuela no Mercosul?

Objetivamos responder essas perguntas ao final desse estudo. Partimos do princípio que o Brasil tem um sistema de financiamento habitacional avançado e objetiva transmitir o método para a Venezuela, utilizando a Caixa Econômica, a fim de fortalecer a economia do país e não enfraquecer o Mercosul com a entrada do novo membro no grupo.

Objetivamos também contribuir com as pesquisas realizadas acerca do Mercosul e do sistema bancário dos países estudados: o Brasil e a Venezuela. 
Para tanto, esta pesquisa utilizará como técnica a pesquisa bibliográfica, mediante a análise de livros, artigos e periódicos, bem como a descrição e análise de uma entrevista realizada com o gerente do escritório de representação internacional da Caixa Econômica Federal localizado na Venezuela, a fim de darmos suporte e incrementarmos os dados adquiridos para a pesquisa em questão.

Ao longo desta monografia discorreremos sobre o Brasil e a Venezuela. Faremos uma contextualização sobre as características do sistema bancário do Brasil no primeiro capítulo e da Venezuela no segundo. Discorreremos, também, acerca dos programas sociais realizados pelos dois países, nessa mesma ordem. Analisaremos a importância do Brasil para o Mercosul, além dos benefícios da entrada da Venezuela no bloco, também nos dois primeiros capítulos respectivamente. Analisaremos, no terceiro capítulo, qual é o interesse de ambos os países em estabelecer uma parceria e relataremos os dados coletados em entrevista realizada com o gerente regional internacional do escritório de representação da Caixa Econômica Federal.

Veremos a seguir uma contextualização geral sobre o Brasil e o sistema bancário deste país. Analisaremos a importância do programa habitacional brasileiro, do qual o banco público Caixa Econômica Federal detêm $80 \%$ do mercado de financiamento nacional de moradias, o que atraiu o interesse do governo da Venezuela. Analisaremos, ainda neste capítulo, a importância do Brasil para o Mercosul. 


\section{CAPÍTULO 1 - BRASIL}

\subsection{Da criação do sistema bancário brasileiro aos dias atuais}

O sistema bancário brasileiro é um dos mais avançados do mundo, apesar de ter sido criado recentemente, se comparado com outros países.

Segundo Chavantes (2009), a formação do sistema financeiro no Brasil teve seu início com a vinda da Família Real portuguesa para o país. Os pagamentos até então eram feitos exclusivamente por troca, sendo as mercadorias utlizidas como moedas - a exemplo do açúcar e do algodão. Pouco tempo depois os brasileiros passaram a utilizar as moedas metálicas originárias de Portugal e de outras partes do mundo. Em 1808, o primeiro banco do Brasil foi criado. Deu-se início, então, à emissão de notas bancárias. O intuito da criação do banco não foi fomentar a produção ou o comércio, mas possibilitar à coroa brasileira a emissão de moeda para suprir as suas necessidades, as quais não eram atendidas apenas com a cobrança de tributos.

Em 1830 surgiram algumas caixas estaduais no Brasil. As primeiras surgiram nos Estados da Bahia, Pernambuco, Alagoas, Minas Gerais e Rio de Janeiro. No dia 12 de Janeiro de 1861 Dom Pedro II assinou o decreto 2.723, o qual aprovava a criação de uma Caixa Econômica e um Monte de Socorro na Corte. Sua finalidade era conceder empréstimos e estimular o hábito de poupar entre a população até então tida como imprevidente, recebendo pequenas poupanças das classes menos abastadas, incluindo os escravos, que podiam economizar para suas cartas de alforria, pagando a eles juros de 6\% a.a., e garantindo a restituição dos depósitos a ela confiados. Antes da criação do Monte de Socorro, existiam no Brasil centenas de casas de penhor, mais conhecidas como Casas de Prego. A origem desse nome deu-se porque era costume dos donos desses estabelecimentos colocarem as jóias empenhadas num prego bem alto, na entrada das lojas, à vista de todos os possíveis interessados em adquirí-las 
em leilão, caso os verdadeiros donos não pudessem resgatá-las. O Monte de Socorro na Corte foi inspirado nos Montes Pio ou Montes de Piedade europeus e tinha por finalidade emprestar, por módico juro e sob penhor, as quantias necessárias para socorrer as necessidades urgentes das classes menos favorecidas, que não tinham acesso a estabelecimentos bancários, principalmente para contrair empréstimos. Instalada na Cadeia Velha, na Rua da Misericórdia, hoje Palácio Tiradentes, a Caixa Econômica do Monte de Socorro emprestava pequenas somas sob a garantia de metais preciosos, brilhantes e outros valores. Aos 4 dias de novembro de 1861, 10 meses depois da assinatura do decreto por D. Pedro II, a Instituição começou oficialmente suas operações no Rio de Janeiro. Na época, o Brasil já tinha quase 10 milhões de habitantes e a população do Rio de Janeiro já chegava a 250 mil moradores. Nos primeiros dias de funcionamento, já era possível identificar algumas tendências que mais tarde se consolidariam. A principal é que a instituição tinha surgido para atender à população mais pobre: as somas depositadas pelos 50 primeiros clientes variavam entre 10 mil e 50 mil réis. Para ter uma idéia do valor, uma boa refeição não saía por menos de 2 mil réis.

Apenas em 1838 o sistema bancário brasileiro inicia suas atividades de fomento à economia por meio da captação de recursos e da concessão de crédito, com a criação do primeiro banco privado do país, o Banco Comercial. Criado por vários comerciantes do Rio de Janeiro, o banco propiciou uma melhora significativa econômico-financeira por meio da expansão da produção agrícola e do aumento da atividade comercial. Entre 1840 e 1889 o sistema bancário contava com 17 casas bancárias, que não podiam emitir moeda e se dedicavam a receber depósito e conceder empréstimos.

Chavantes (2009) afirma que até o ano de 1905 não existia nenhuma regulamentação estatal no sistema bancário brasileiro. Com a consolidação do Banco do Brasil como agente do Estado, o setor começou a ter normas nacionais de regulação e de controle. Em 1920 foi criado o primeiro órgão fiscalizador dos bancos existentes. A Inspetoria Geral dos 
Bancos, prevista no artigo 5을 do Decreto ํㅜ 4.182 , de 13.11.20, e no artigo $2^{\circ}$ da Lei no 4.230, de 31.12.20. O Decreto oㅜ 14.728, de 16.03.21, aprovou o regulamento para a fiscalização dos bancos e das casas bancárias. $\mathrm{O}$ mesmo decreto criou a carteira de redesconto, que possibilitava aos bancos nacionais maiores garantias para suas operações de crédito, pois em caso de necessidade poderiam recorrer ao Banco do Brasil, o que diminuiu a vulnerabilidade do sistema.

Fortuna (1992, p.4) afirma que em 1945 nasceu a Superintendência da Moeda e do Crédito (SUMOC), por meio do Decreto-Lei no 7.293, de 02.02.45. Incumbida de exercer o controle do mercado monetário, a SUMOC recebeu do Banco do Brasil as atribuições da carteira de redesconto e começa a definir os valores dos depósitos compulsórios dos bancos, ou seja, nasce a autoridade monetária nacional. Em 1964 foram criados o Conselho Monetário Nacional (CMN) e o Banco Central do Brasil, em substituição à SUMOC, através da Lei oㅡ 4.595, de 31.12.64, a qual regulamentou o Sistema Financeiro Nacional (SFN). Muito mais do que institucionalizar o Sistema Financeiro Nacional, por meio de agentes bem definidos a reforma instituída em 1964 proporcionou ao sistema bancário uma maior capacidade de captação de recursos com a institucionalização da correção monetária.

A criação da correção monetária, que inicialmente serviu para remunerar apenas os títulos públicos emitidos pelo Estado, foi gradativamente utilizada para a remuneração de todos os depósitos captados pelo sistema bancário gerando taxas de juros positivas. Antes da reforma, a Lei de Usura de 1933 autorizava a remuneração máxima de 12\% ao ano de juros sobre os depósitos captados, o que em períodos de elevada inflação desmotivava os depósitos nas instituições instaladas no país, fomentando a compra de moeda estrangeira ou de imóveis. A nova condição de remuneração financeira dos depósitos proporcionou uma ampliação da rede de unidades visando à captação de novos recursos e a concessão de empréstimos a prazos mais longos. Nesta reforma foi criado $O$ Conselho Monetário Nacional (CMN) e o Banco Central do Brasil, executor das ações 
do $\mathrm{CMN}$ e responsável pela política monetária e creditícia, pela emissão de papel-moeda, pela carteira de redesconto e pela custódia dos depósitos compulsórios e demais funções delegadas anteriormente a SUMOC, ao Banco do Brasil e ao Tesouro Nacional.

Doellinger (2009) relata que em 1988 ocorreu uma grande mudança no enfoque do sistema bancário, o qual deixou de ser restrito a determinadas operações, possibilitando a oferta de todos os serviços financeiros. Nasceram os bancos múltiplos, instituídos pela Resolução № 1.524 de 21.09.88 do $C M N$, os quais são autorizados a executar atividades que eram realizadas separadamente por corretoras de seguros, distribuidoras de títulos e valores e demais operações financeiras ou de serviço.

A criação dos bancos múltiplos possibilitou aos bancos o comando centralizado de várias instituições financeiras e também de outros ramos, como o industrial e de serviço, ou seja, ampliou a capacidade de atuação e controle do sistema bancário no território.

As mudanças instituídas em 1964 e em 1988 alteraram com muita intensidade a atuação das instituições bancárias no país, mas um outro marco de grande importância no sistema bancário nacional foi a implantação do Plano Real em 1994.

Este Plano, segundo Doellinger (2009), foi um programa brasileiro de estabilização econômica, com o objetivo principal de controle da hiperinflação. Ele foi iniciado em fevereiro de 1994 com a publicação da Medida Provisória no 434 no Diário Oficial da União. Tal Medida Provisória instituiu a Unidade Real de Valor (URV), estabeleceu regras de conversão e uso de valores monetários, iniciou a desindexação da economia, e determinou o lançamento de uma nova moeda: o Real.

O país apresentou várias crises inflacionários até a criação do Plano, o que possibilitou aos bancos altos lucros apenas com a remuneração dos depósitos pelas taxas de juros pagas pelos papéis emitidos pelo Governo Federal, principalmente após a instituição da correção monetária em 1964. A moeda nacional do Brasil mudou de nome 
várias vezes, principalmente nos períodos de altos índices de inflação no país. Na maioria das renomeações monetárias, foram cortados três dígitos de zero. Esta estratégia impediu que um quilo de carne custasse cerca de quatro milhões de unidades da moeda vigente, por exemplo.

Segue abaixo um quadro contendo as alterações sofridas pela moeda brasileira entre 1942 e os dias atuais:

Tabela 1 - Nomenclatura da Moeda Brasileira entre 1942 e 2010

\begin{tabular}{|l|l|}
\hline Período & Nomenclatura da Moeda \\
\hline Até 1942 & Réis \\
\hline De 1942 a 1967 & Cruzeiro \\
\hline De 1967 a 1970 & Cruzeiro Novo \\
\hline De 1970 a 1986 & Cruzeiro \\
\hline De 1986 a 1989 & Cruzado \\
\hline De 1989 a 1990 & Cruzado Novo \\
\hline De 1990 a 1993 & Cruzeiro \\
\hline De 1993 a 1994 & Cruzeiro Real e Unidade Real de Valor (URV) \\
\hline De 1994 até hoje & Real \\
\hline
\end{tabular}

Doellinger (2009) afirma que as crises inflacionárias ocorridas na segunda metade do século XX foram geradas ou pelo aumento dos gastos públicos, por crises internacionais, como a do petróleo na década de 1970 ou pelo aumento dos juros da dívida externa. $O$ auge desse processo aconteceu nas décadas de 1980/90, quando a taxa de inflação chegou a atingir $2.751 \%$ entre fevereiro de 1989 e fevereiro de 1990, período em que o governo brasileiro instituiu os diversos planos econômicos objetivando minimizar o processo inflacionário. Todos os planos anteriores ao Plano Real fracassaram na intenção de resolver o crônico problema inflacionário do país. Com base nos fracassos anteriores o Plano Real foi elaborado em julho de 1994 calcado na paridade do Real com o Dólar e o não congelamento de preços. Após alguns ajustes, esse Plano se consolidou e possibilitou ao país taxas de inflação nos patamares de países do centro do sistema capitalista. 
Meireles (2008) afirma que, com o impacto do fim do processo inflacionário verificou-se a queda na participação do setor financeiro no PIB. Esse quadro revelou a ineficiência na atuação de alguns bancos, dos quais vários não suportaram o fim dos ganhos com o processo inflacionário e conseqüentemente não conseguiram se reestruturar ao novo modelo vigente, gerando uma grande crise no sistema bancário. Com a redução das taxas de inflação e consequente estabilização da economia, o sistema bancário foi submetido a grandes alterações. Os bancos se viram impelidos a efetuar com urgência uma reestruturação interna e a reorganizar estrategicamente suas atividades, desde ajustes na sua estrutura patrimonial, passando pela revisão no seu padrão de rentabilidade, até processos de fusões e incorporações. Os bancos mais fortes sobreviveram.

Inúmeras medidas de aprimoramento nas áreas de normas, fiscalização e supervisão bancária do Banco Central resultaram em maior solidez e transparência na atividade bancária. $O$ Brasil regulamentou as adaptações das instituições financeiras brasileiras às normas do Acordo de Basiléia que resultaram em substancial elevação dos valores mínimos de capital realizado e patrimônio liquido, na criação de uma central de riscos e na vinculação do capital mínimo à qualidade dos ativos bancários.

A partir do ano 2000, os bancos passaram obrigatoriamente a classificar o risco de seus empréstimos, e também a estabelecer correspondentes provisões para perdas, sob critérios mais amplos e conservadores. Antes, os parâmetros diziam respeito somente ao atraso nos pagamentos e à existência ou não de garantias. Agora existem outros níveis de risco que levam em consideração, além dos critérios anteriores, a qualidade do devedor, o tipo, a destinação e o valor do empréstimo. As novas regras exigem uma provisão maior e mais ajustada de reservas em relação às efetivas condições de risco de crédito nas carteiras dos bancos.

A nova estrutura, que resultou de todo esse processo de transformação, concentração, consolidação e regulamentação da atividade bancária iniciado com o Plano Real, apresenta bancos saneados, adequadamente capitalizados e assumindo menores riscos, o que os torna 
mais preparados para enfrentar e sobreviver aos efeitos de crises externas e internas.

O Brasil dispõe hoje, reconhecidamente, de um sistema financeiro eficiente, por qualquer padrão de comparação internacional, e sólido, capaz de enfrentar os desafios do financiamento do desenvolvimento. Todas essas características tornam esse sistema o mais rentável do mundo.

\subsection{A função social do banco público brasileiro - A Caixa Econômica Federal}

Fortuna (1992, p.9) afirma que a facilidade de atendimento ao grande público levou os órgãos da administração pública a utilizar intensamente a rede bancária nacional na arrecadação de sua receita. Paralelo aos recebimentos e pagamentos, o governo passou a utilizar os bancos para realizar pagamentos dos beneficiários da previdência e para realizar o pagamento dos programas sociais.

A Caixa Econômica Federal, o único banco de iniciativa 100\% pública, passou a realizar o pagamento de todos os programas sociais, além de ser o agente do Fundo de Garantia dos Trabalhadores Brasileiros, o FGTS. Este banco centraliza todas as contas recolhedoras do FGTS existentes na rede bancária e administra a arrecadação desse fundo e o pagamento dos valores aos trabalhadores. A Caixa também é responsável por efetuar o pagamento dos programas Bolsa Família e Bolsa Escola, dentre outros.

A Caixa Econômica Federal é o maior banco público da América Latina. O banco não possui apenas agências no país, mas também conta com escritórios internacionais no Japão, Estados Unidos da América e Venezuela, além de realizar parcerias com bancos estrangeiros para facilitar a transferência de recursos de famílias que moram no exterior e querem enviar numerário para o Brasil.

Como banco público, desde sua criação, a Caixa Econômica Federal estabeleceu estreitas relações com a população, assistindo suas 
necessidades imediatas por meio de poupança, empréstimos, FGTS, PIS, seguro-desemprego, crédito educativo, financiamento habitacional e transferência de benefícios sociais. Além disso, o banco prioriza setores como habitação, saneamento básico, e prestação de serviços. O banco também tem projetos de infra-estrutura em parceria com o poder público. Além de disponibilizar recursos, a Caixa auxilia prefeituras e governos estaduais a projetarem e acompanharem com eficiência obras promotoras de desenvolvimento urbano.

Segundo o Balanço Social 2005 da Caixa Econômica Federal (2005, p. 4), de 2003 a 2005, a Caixa repassou mais de $R \$ 294$ bilhões aos municípios brasileiros, com recursos próprios e governamentais e de 2005 a 2007, a empresa repassou mais de $R \$ 440$ bilhões, conforme apresentado nas tabelas 2 e 3 a seguir:

Tabela 2 - Total de Recursos Caixa entre 2003 e 2005

\begin{tabular}{|c|c|c|c|c|c|}
\hline $\begin{array}{c}\text { Grupo de } \\
\text { Informações }\end{array}$ & $\begin{array}{l}\text { Valor } \\
2003\end{array}$ & $\begin{array}{l}\text { Valor } \\
2004\end{array}$ & $\begin{array}{c}\text { VAR (\%) } \\
2003 / 2004\end{array}$ & $\begin{array}{l}\text { Valor } \\
2005\end{array}$ & $\begin{array}{c}\text { VAR (\%) } \\
2004 / 2005\end{array}$ \\
\hline $\begin{array}{l}\text { Transferência de } \\
\text { Renda* }\end{array}$ & 3.141 & 5.152 & $64,00 \%$ & 6.484 & $25,80 \%$ \\
\hline Trabalho e Renda & 48.812 & 59.303 & $21,50 \%$ & 63.694 & $7,40 \%$ \\
\hline$\underset{\star \star}{\text { Emprego e Renda PF }}$ & 14.789 & 17.443 & $18,00 \%$ & 19.880 & $14,00 \%$ \\
\hline Emprego e Renda PJ & 5.830 & 8.847 & $51,70 \%$ & 16.442 & $85,80 \%$ \\
\hline $\begin{array}{l}\text { Desenvolvimento } \\
\text { Urbano - Habitação }\end{array}$ & 4.492 & 5.481 & $22,00 \%$ & 8.709 & $58,90 \%$ \\
\hline $\begin{array}{l}\text { Desenvolvimento } \\
\text { Urbano - Saneamento } \\
\text { e Infra-estrutura }\end{array}$ & 1.984 & 2.556 & $28,80 \%$ & 1.581 & $-38,20 \%$ \\
\hline $\begin{array}{l}\text { Apoio à Gestão } \\
\text { Pública }\end{array}$ & 28 & 109 & $289,30 \%$ & 23 & $-79,00 \%$ \\
\hline Agricultura & 127 & 200 & $57,50 \%$ & 42 & $-79,30 \%$ \\
\hline Educação e Desporto & 62 & 129 & $108,40 \%$ & 232 & $79,20 \%$ \\
\hline Saúde & 144.8 & 229.9 & $58,73 \%$ & 342.4 & $48,95 \%$ \\
\hline Total & 79.548 & 99.669 & $25,30 \%$ & 117.49 & $16,10 \%$ \\
\hline
\end{tabular}

* Incluídos em 2005 os programas: De volta para casa, Pró-jovem, Bolsa Atleta e Emergência Contra a Seca.

** Incluído Cartão de Crédito nos anos 2003, 2004 e 2005. 
Tabela 3 - Total de Recursos Caixa entre 2005 e 2007

\begin{tabular}{|l|r|r|r|r|r|}
\hline \multicolumn{1}{|c|}{$\begin{array}{c}\text { Grupo de } \\
\text { Informações }\end{array}$} & \multicolumn{1}{c|}{$\begin{array}{c}\text { Valor } \\
\mathbf{2 0 0 5}\end{array}$} & $\begin{array}{c}\text { Valor } \\
\mathbf{2 0 0 6}\end{array}$ & $\begin{array}{c}\text { VAR (\%) } \\
\mathbf{2 0 0 5 / 2 0 0 6}\end{array}$ & $\begin{array}{r}\text { Valor } \\
\mathbf{2 0 0 7}\end{array}$ & $\begin{array}{c}\text { VAR (\%) } \\
\mathbf{2 0 0 6 / 2 0 0 7}\end{array}$ \\
\hline $\begin{array}{l}\text { Transferência de } \\
\text { Renda* }\end{array}$ & 6.484 & 7.594 & $17,30 \%$ & 9.007 & $18,60 \%$ \\
\hline Trabalho e Renda & 63.694 & 68.835 & $8,10 \%$ & 88.486 & $28,50 \%$ \\
\hline $\begin{array}{l}\text { Emprego e Renda PF } \\
\star *\end{array}$ & 19.880 & 23.750 & $27,30 \%$ & 27.733 & $16,80 \%$ \\
\hline Emprego e Renda PJ & 16.442 & 22.826 & $38,90 \%$ & 25.853 & $13,30 \%$ \\
\hline $\begin{array}{l}\text { Desenvolvimento } \\
\text { Urbano - Habitação }\end{array}$ & 8.709 & 14.179 & $64,00 \%$ & 21.158 & $49,20 \%$ \\
\hline $\begin{array}{l}\text { Desenvolvimento } \\
\text { Urbano - Saneamento } \\
\text { e Infra-estrutura }\end{array}$ & 1.581 & 4.300 & $193,30 \%$ & 15.700 & $265,10 \%$ \\
\hline Apoio à Gestão Pública & 23 & 58 & $176,20 \%$ & 163 & $181,00 \%$ \\
\hline Agricultura & 42 & 333 & $29,10 \%$ & 577 & $73,30 \%$ \\
\hline Educação e Desporto & 232 & 258 & $21,70 \%$ & 367 & $42,20 \%$ \\
\hline Saúde & 342.4 & 489 & $15,60 \%$ & 929 & $90,00 \%$ \\
\hline Total & $\mathbf{1 1 7 . 4 9}$ & $\mathbf{1 4 2 . 6 2 2}$ & $\mathbf{2 2 , 6 0 \%}$ & $\mathbf{1 8 9 . 9 7 3}$ & $\mathbf{3 3 , 2 0 \%}$ \\
\hline
\end{tabular}

Como empresa pública, em consonância com as diretrizes do Governo Federal, a Caixa Econômica Federal também atua em eventos e ações que possuam aderência às suas atividades e que estejam vinculados aos seus objetivos. Essa participação é feita através do patrocínio de projetos.

De acordo com o Balanço Social 2007 da Caixa Econômica Federal (2007, p.47), os projetos de patrocínio aprovados são priorizados de acordo com as seguintes políticas:

- Inclusão social: projetos de sustentabilidade, que favoreçam a inclusão social e apresentem contrapartidas sociais em concordância com a missão da CAIXA;

- Desenvolvimento humano: projetos que propiciem o desenvolvimento humano, a participação sociocultural e geração de emprego/renda; os que explicitem benefícios voltados para comunidades carentes ou público jovem;

- Reciprocidade negocial: projetos que apresentem afinidade com as estratégias negociais da CAIXA, priorizando-os de acordo com o grau de relevância e sintonia com focos de atuação;

- Valores nacionais: projetos que permitam a valorização, resgate e manutenção de riquezas culturais;

- Democratização: projetos que primam pela democratização na concorrência pelos recursos e que permitam a itinerância de grandes eventos patrocinados; 
- Descentralização: projetos que promovam as diversas manifestações artísticas, culturais e de valorização da prática do esporte, em todo o território brasileiro;

- Transparência: projetos pautados em padrões de conformidade, qualidade, ética, relação custo/benefício e resultados efetivos para a sociedade.

As ações de patrocínios culturais são efetivadas por meio de investimento financeiro da Caixa Econômica ou com utilização dos benefícios das leis de incentivo a culturas municipais, estaduais e federais.

A empresa afirma em seu balanço social que em 2005, a Caixa investiu R\$ 23,5 milhões no patrocínio de 635 eventos e 49 projetos culturais, incluindo os projetos de cunho sociocultural. Em 2006, a empresa investiu mais de $R \$ 15$ milhões em patrocínio esportivo e em 2007 mais de $\mathrm{R} \$ 24$ milhões no mesmo setor, conforme podemos observar no balanço social do ano de 2007, apresentado pela empresa. O banco também promoveu acesso gratuito da população à Cultura e à Arte durante o período relatado, contribuindo assim para o fortalecimento das economias locais por meio da cultura e inclusão social.

\section{3 - O programa de financiamento habitacional brasileiro}

O governo brasileiro tem dado prioridade ao programa de financiamento habitacional no país. Incentivando o programa habitacional, o governo fomenta a construção civil e a criação de novos empregos no setor. Além disso, o governo cumpre seu objetivo de atingir o maior número de brasileiros com residência própria.

Para corroborar com tal objetivo, o governo brasileiro criou o Programa Minha Casa Minha Vida. Discorremos a seguir sobre este programa a fim analisarmos o maior programa de financiamento habitacional da atualidade do país. 


\subsection{1- O programa Minha Casa Minha Vida}

Lançado em maio do ano de 2009, o programa habitacional Minha Casa Minha Vida foi criado, segundo o Governo Federal (2009, p.12), com o objetivo de diminuir o déficit de moradia no Brasil. Para tanto, o governo almeja construir um milhão de casas nas cidades com população acima de cem mil habitantes e para famílias que possuem renda de até dez salários mínimos. Os limites de valores do imóvel e da prestação variariam de acordo com a faixa de renda e a região. O valor máximo do imóvel, por exemplo, não pode ultrapassar cento e trinta mil reais na faixa de renda até seis salários mínimos. As famílias que forem financiar o imóvel poderão comprometer até $10 \%$ da renda e o prazo para pagamento será de no máximo dez anos.

Para desenvolver o financiamento dessas moradias, o governo brasileiro irá utilizar exclusivamente os serviços da Caixa Econômica Federal, através da alocação de recursos para o banco, o qual dividirá o incentivo entre os municípios contemplados. O município por sua vez irá cadastrar as famílias que se enquadram no programa a fim de selecionar as que estão aptas a receberem o incentivo do governo. As famílias contempladas deverão procurar o banco escolhido pelo governo para darem início ao financiamento com os incentivos do programa.

\subsection{2 - O sistema de financiamento habitacional}

Mendonça (2009) afirma que uma peculiaridade do sistema financeiro brasileiro é a presença de mecanismos de direcionamento de crédito, fundados no diagnóstico de que, por razões diversas, alguns segmentos da economia merecem tratamento diferenciado. $O$ formato assumido pelo direcionamento de crédito no Brasil pode ser entendido por meio de processos de naturezas distintas. O primeiro impõe a vinculação entre instrumentos de captação e aplicação de recursos. É este o caso do direcionamento para crédito imobiliário de $65 \%$ dos recursos captados por 
cada uma das instituições financeiras por meio de depósitos de poupança. Outros dois segmentos nos quais há vinculação entre captação e aplicação são os de empréstimos rurais e microcrédito. $O$ segundo processo de direcionamento parte da existência de grandes fundos fiscais e parafiscais, tais como Fundo de Amparo ao Trabalhador (FAT), Fundo de Garantia de Tempo de Serviço (FGTS) e Fundos Constitucionais. Estes fundos servem como instrumento fundamental de funding para segmentos específicos da economia brasileira, tais como os financiamentos de longo prazo fornecidos pelo BNDES a partir dos recursos do FAT; financiamentos concedidos majoritária, mas não exclusivamente, pela Caixa Econômica Federal, com funding do FGTS, à habitação, saneamento e infraestrutura urbana, ou os financiamentos destinados a regiões específicas, a partir dos recursos dos Fundos Constitucionais. Cabe destacar que o uso destes recursos ocupa papel fundamental no financiamento dos segmentos listados, com desdobramentos importantes para a própria dinâmica de funcionamento da economia brasileira.

Por priorizar a habitação, a Caixa Econômica Federal é detentora da maior parte do mercado de financiamento habitacional brasileiro. Diante do fator, este é o banco escolhido pelo governo para trabalhar com os programas de incentivo à população.

Além disso, a Caixa Econômica é referência no exterior. Isto ocorre devido a sua experiência no ramo e por ser o banco de preferência do governo no setor.

Segundo Reis (2009), mesmo durante a crise econômica mundial, a Caixa Econômica realizou empréstimos para habitação no valor total de $\mathrm{R} \$$ 17,4 bilhões, nos primeiros seis meses do ano de 2009, o que representa um aumento de $90 \%$ em relação ao mesmo período do ano anterior.

Este cenário favorece o crescimento do PIB do país, o que consequentemente favorece a economia e atrai observadores estrangeiros. 


\section{4 - O Brasil e o Mercosul}

O Mercosul é um bloco de integração regional, o qual se iniciou em 26 de março de 1991, com a assinatura do Tratado de Assunção pelos governos da Argentina, Brasil, Paraguai e Uruguai. O bloco conta com cinco países associados, os quais são: Bolívia, Chile, Colômbia, Equador e Peru. Em 2006 iniciou-se o processo de entrada da Venezuela no Mercosul, o qual ainda não foi finalizado.

Apesar de ter passado por uma etapa de estagnação o Mercosul tem grande importância para a América Latina. Notadamente, o Brasil é o país de maior influência no bloco econômico. O país é a principal unidade econômica do mesmo e corresponde a 70\% do Produto Interno Bruto (PIB) agregado do conjunto. O país também tem superávit comercial com todos os países membros. Além de importar mais, o Brasil exerce menor pressão exportadora sobre seus vizinhos ao atender um consumo interno em expansão.

O Brasil é o maior mercado latino-americano, logo é um grande consumidor. O país consome, por exemplo, energia, seja petróleo, gás natural ou eletricidade, produtos dos quais seus vizinhos, e membros do Mercosul, são exportadores.

O Brasil passou pela crise mundial sem sofrer muitas conseqüências, principalmente no setor bancário, o que também o faz um país de destaque no bloco econômico.

Segundo Mendonça (2009), isso ocorreu porque houve a redução da inflação, obtida através da implementação do Plano Real, o qual impactou fortemente o sistema devido à importância do lucro inflacionário para as instituições financeiras. Essa redução inflacionária preparou o país para não sofrer tantas conseqüências na crise que viria.

O país também passou pela crise sem muitas conseqüências devido ao processo de liberalização financeira, que possibilitou a entrada de capitais estrangeiros no sistema financeiro. 
Mendonça (2009) afirma que O Banco Central Brasileiro implementou também uma série de medidas para a adequação de sua estrutura de regulação e supervisão ao que se colocava como sendo a nova necessidade do mercado financeiro e de capitais, qual seja, a construção de um arcabouço voltado para a mensuração, avaliação e administração de riscos.

O sistema financeiro brasileiro é mais complexo e maior, não só em termos absolutos, mas também em termos relativos, que os sistemas argentino, uruguaio e paraguaio, em especial após o encolhimento dos dois primeiros no período posterior à crise da década de 90 .

Todos esses fatores fazem do Brasil um país de destaque no Mercosul, não somente no setor financeiro, mas em todos os setores. 


\section{CAPÍTULO 2 - VENEZUELA}

Discorreremos a seguir sobre o sistema bancário venezuelano. Analisaremos a atuação do governo no controle das instituições financeiras, além dos programas sociais realizados pelo governo no país. Faremos, também, um relato sobre o programa habitacional oferecido para a população desse país, bem como dissertaremos sobre a entrada da Venezuela no Mercosul.

\subsection{O sistema bancário venezuelano}

Segundo Marino (2006), na década de 90, recursos aplicados nos bancos venezuelanos eram revertidos em investimentos fora do país. A Lei Geral dos Bancos e Outras Instituições Estrangeiras fora então criada para evitar o refúgio de capital para o exterior. Essa lei foi baseada em três elementos principais, os quais são:

I. Controle total e muito rígido, baseado na legislação em vigor, o qual é realizado pela Superintendência dos bancos;

II. Nomeação de funcionários altamente qualificados e de confiança do governo;

III. Acompanhamento e supervisão das instituições financeiras pelas entidades de controle criado pelo Estado através da legislação vigente.

Para obter este estrito controle e garantir que não haveria mais evasão de numerários do país, o governo venezuelano reforçou a Superintendência dos Bancos.

Marino (2006) afirma que no dia 3 de novembro de 2001, o Presidente da República, no exercício das suas atribuições, conferidas pelo parágrafo 8 do artigo 236 da Constituição da República Bolivariana da Venezuela, e em conformidade com o disposto no artigo $1^{\circ}$ da Lei que autoriza o Presidente da República a ditar decretos com Força da Lei, emitiu o Decreto $\mathrm{n} \cong 1.526$, o Decreto com Força de Lei de Reforma da Lei Geral dos Bancos e Outras Instituições Financeiras. A finalidade deste decreto é a 
regulamentação e definição de como os bancos e outras instituições financeiras que tenham sede no país possam funcionar. Da mesma forma define e regulamenta as funções dos órgãos criados pelo Estado venezuelano, que, no exercício da sua função de supervisão e controle, determina e monitora o desempenho e funcionamento de todas as instituições bancárias.

O sistema financeiro venezuelano, como qualquer outro sistema, é um complexo conjunto de órgãos interligados e interdependentes entre si, que não podem ser analisado isoladamente. Ele envolve todas as entidades governamentais que, de certa forma tem um impacto no desenvolvimento e implementação de bancos e finanças no país.

Segue abaixo um organograma contendo a estrutura dos órgãos controladores do banco venezuelano.

Figura 1 - Estrutura do Sistema Bancário Venezuelano

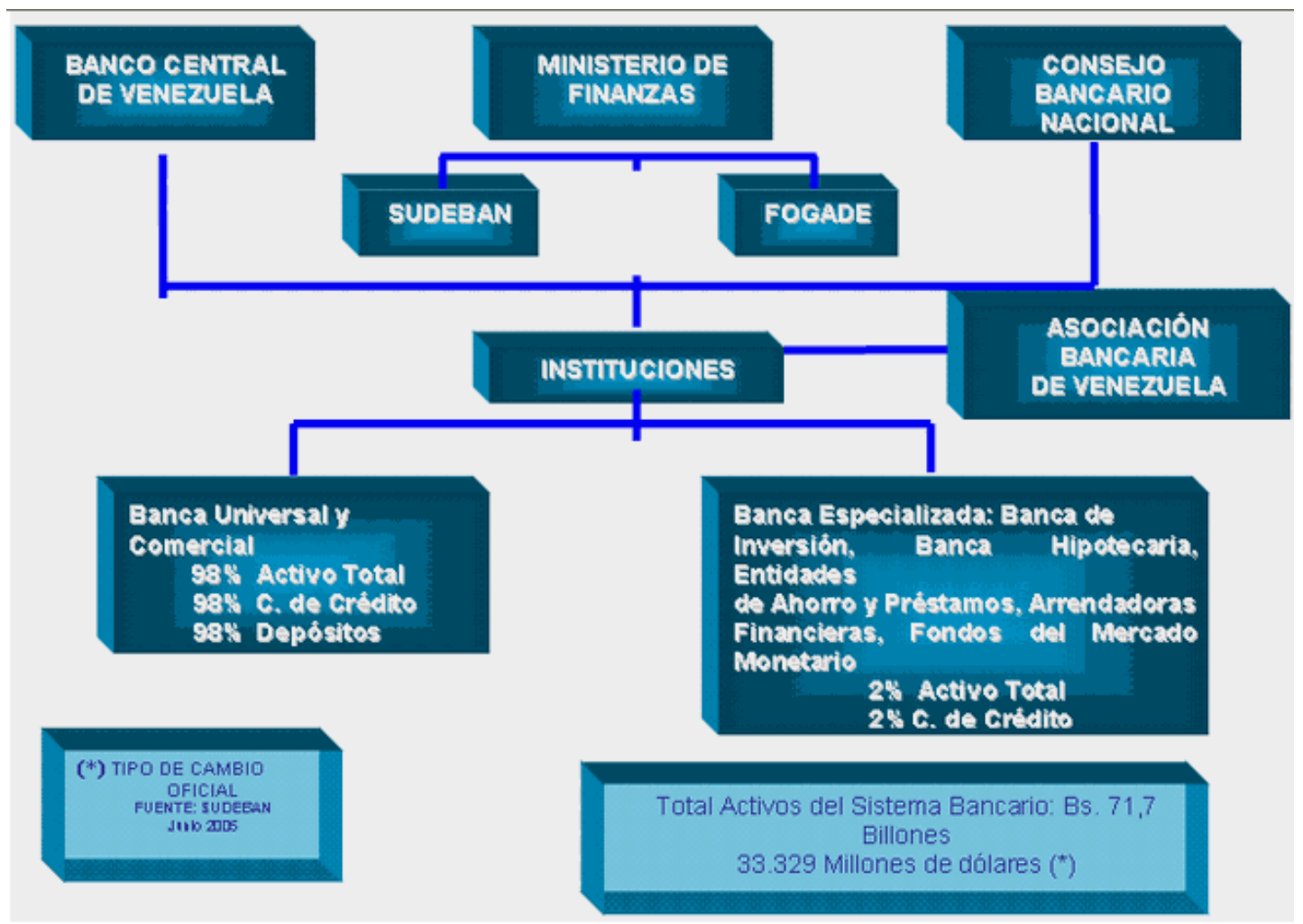


Discorreremos abaixo sobre cada órgão do sistema bancário da Venezuela.

\subsubsection{O Conselho Nacional dos Bancos}

Segundo Marino (2006), o Conselho Nacional de Bancos foi fundado em 14 de março de 1940, de acordo com o disposto na lei bancária venezuelana de 24 de janeiro de 1940. Atualmente regido pelo disposto no Título I, Capítulo XI, da lei atual de bancos e outras instituições financeiras. O disposto prevê que o Conselho Nacional de Bancos será sediado em Caracas e será composto por um representante de cada um dos bancos e instituições financeiras reguladas por esta lei ou por leis especiais, com exceção do Banco Central da Venezuela. Segundo a lei, todas as instituições financeiras, inclusive os bancos estrangeiros são obrigatoriamente membros do Conselho Nacional de Bancos.

A lei também estabelece que o Conselho Nacional dos Bancos tenha dois órgãos do governo deliberativos: a Assembléia e a Junta Diretiva.

O conselho é composto por um presidente, dois vice-presidentes e quatro membros que serão eleitos pela Assembléia. Este presidente ocupará o cargo por um ano. Os membros do Conselho podem ser reeleitos.

A Assembléia se reunirá, pelo menos uma vez por mês, sempre que convocada pelo seu Presidente. A Assembléia também reunir-se-á a pedido do presidente do Banco Central da Venezuela, do presidente do Fundo de Garantia de Depósitos e da Banca, do Superintendente de Bancos ou de dois membros do Conselho.

A Lei também estabelece os seguintes poderes ao Conselho:

- Estudar as condições bancárias e econômicas do país e enviar informes com suas conclusões e recomendações à Superintendência de Bancos e do Banco Central da Venezuela;

- Responder os questionamentos da Superintendência dos Bancos e do Banco Central de Venezuela. 
- O conselho tem a função conciliatória nas disputas que possam surgir entre os membros do mesmo.

- Para responder os questionamentos da Superintendência e do Banco Central da Venezuela, além de tomar as decisões conciliatórias a Assembléia deve decidir por maioria igual ou superior a $75 \%$ dos membros presentes na reunião.

A Lei também estabelece que o presidente do Conselho Nacional do Bancário é parte integrante da Assembléia do Fundo de Garantia de Depósitos.

\subsubsection{A Superintendência dos Bancos e Outras Instituições Financeiras}

Marino (2006) afirma que a Superintendência dos Bancos e Outras Instituições Financeiras foi criada pela Lei Bancária de 24 de janeiro de 1940. A sua criação substituiu o órgão de fiscalização geral do Ministério das Obras Públicas, o qual tinha sido encarregado das funções de acompanhamento e avaliação dos bancos. A Superintendência dos Bancos e Outras Instituições Financeiras - Sudeban - é um órgão autônomo, de caráter técnico e especializado, com personalidade jurídica, patrimônio próprio e independente do Fisco Nacional, o qual tem como função principal monitorar, controlar e fiscalizar as instituições financeiras regidas pela Lei Geral de Bancos e Outras Instituições Financeiras. Ela foi criada para evitar crises bancárias e permitir uma operação segura e eficiente de Sistema Financeiro Venezuelano.

A Superintendência tem autonomia funcional, assistência administrativa e financeira no exercício das suas competências nos termos estabelecidos na Lei Geral de Bancos e Outras Instituições Financeiras. Ela somente está sujeita ao posterior controle da Controladoria Geral da República.

A Lei Geral de Bancos e Outras Instituições Financeiras estabelece que a Superintendência dos Bancos e Outras Instituições 
Financeiras deve exercer inspeção, supervisão, regulação e controle dos bancos em geral, das casas de câmbio, escritórios de representação de bancos estrangeiros e financeiras. Essa supervisão é feita por meio de funções desempenhadas por seis gerências chaves de gestão de inspeção, as quais têm a responsabilidade de efetuar dois tipos de controle fundamentais: o controle direto e o controle indireto.

A fim de unificar as operações bancárias, a Superintendência elaborou um manual que padronizava a apresentação dos resultados dos bancos.

Após um período de bonança, um crítico quadro de retiradas em massa, compra de divisas e uma diminuição significativa nos depósitos abalou o mercado financeiro e a economia venezuelana, colocando o sistema bancário em uma situação difícil. As autoridades venezuelanas tiveram que colocar em prática medidas de emergência.

Marino (2006) afirma que em 1962, o sistema financeiro começou a dar sinais de recuperação após ter recebido o auxílio do Banco Central da Venezuela.

Uma nova etapa na Sudeban começou após esta crise marcada pela fuga de capitais e grandes desequilíbrios macroeconômicos que terminaram em intervenções bancárias, as quais originaram a criação do Fundo de Garantia de Depósitos e Proteção Bancária - FOGADE - em 20 de março de 1985.

A alteração parcial ao Direito Bancário, sofrida em fevereiro de 1988, deu plenos poderes à Superintendência dos Bancos para a prática de medidas de intervenção, em casos nos quais forem detectadas irregularidades na gestão de qualquer banco. Como as medidas adotadas não foram as adequadas, um colapso no sistema financeiro ocorreu em 1994. Ficou então evidente a debilidade funcional da Superintendência dos Bancos naquela década, pois apesar dos esforços não conseguiram impedir o desfecho fatal da falência de várias instituições financeiras.

Após o desfecho da crise de 1994, a Superintendência dos Bancos, juntamente com o Estado, por meio da Superintendência para a 
Promoção e Defesa da Livre Concorrência, decidiu melhorar o seu desempenho, estabeleceu três objetivos fundamentais para iniciar a sua reestruturação, os quais são:

- Assegurar, mediante acompanhamento e controle, que as instituições financeiras exerçam suas atividades de acordo com as diretrizes da Superintendência;

- Zelar pela transparência e a estabilidade do sistema financeiro;

- Garantir aos depositantes o investimento de seus depósitos em operações próprias das instituições financeiras a fim de diminuir o risco moral.

Para realizar estes objetivos, a Superintendência dos Bancos propôs um programa de avaliação de sua equipe e de seu desempenho, bem como exigiu maior responsabilidade aos conselhos de administração das entidades, além de estabelecer inspeções periódicas.

A implementação do novo enfoque de supervisão por parte da Superintendência, com o apoio da junta de emergência financeira, e a atuação responsável dos acionistas e diretores dos bancos, são fatores que têm contribuído para a melhoria do sistema bancário doméstico como podemos observar nos resultados produzidos a partir de 1994.

Depois de a crise ter normalizado, houve uma reestruturação profunda da SUDEBAN. A reestruturação ocorreu desde aspectos tecnológicos, passando por melhor planejamento de inspeções, até valorização e treinamento de pessoal. Também executou medidas externas, tais como regulamentação das regras para fusões bancárias, das regras para o arquivamento e registro de informações financeiras e da mecanização da informações.

Para Marino (2006), atualmente a SUDEBAN apresenta novo ar de modernidade, obtendo instalações totalmente automatizadas, o que a faz um dos órgãos reguladores mais modernos da América Latina. A lei atual lhe dá autonomia e independência suscetível para constituir uma instituição dotada de poder para exercer um amplo controle sobre todas as instituições financeiras. 


\subsubsection{O Fundo de Garantia de Depósito e Proteção Bancária (FOGADE)}

Marino (2006) afirma que durante a grande depressão dos anos 1929-39, nos Estados Unidos um grande número de bancos, especialmente os pequenos, quebrou. Para diminuir os efeitos desta crise, a administração de Franklin Delano Roosevelt, criou a Corporação Federal de Depósito e Seguro, entidade responsável pela administração do seguro dos depósitos bancários. Entre os anos de 1934 e 1977, a Corporação Federal teve que assumir a quebra de 541 bancos naquele país. Em 238 dos casos, a Corporação teve que comprar e depois revender os bancos, enquanto nos casos restantes, teve que decretar falência e ressarcir seus investidores.

Obtendo o modelo norte-americano como exemplo, a Venezuela realizou uma série de intervenções e posteriores liquidações, tais como a do Banco Nacional de Desconto - cuja liquidação iniciada há vários anos ainda não foi concluída -, do Banco do Comércio e do custoso salvamento do Banco dos Trabalhadores da Venezuela e o pagamento dos depósitos a seus clientes. Todas essas intervenções ocorreram com recursos do Tesouro Nacional, o qual não tinha obrigação de fazê-lo.

Por estas razões, em 1985, o governo instituiu o Fundo de Garantia de Depósitos e Proteção Bancária - FOGADE, por meio do Decreto $\mathrm{n} \cong 540$ de 20-3-1985 - alterado pelo Decreto $\mathrm{n} \cong 651$-, contendo o seu Estatuto Orgânico.

Atualmente, o regime jurídico do FOGADE está contido no Parágrafo III da Lei Geral dos Bancos e Outras Instituições Financeiras, a qual entrou em vigor em 19 de Novembro de 1993. O artigo 280 da mesma lei prevê que o Fundo de Garantia de Depósito e Proteção Bancária é um instituto autônomo com personalidade jurídica própria e independente do Tesouro Nacional. O Fundo está compreendido no âmbito do Ministério das Finanças, com a única finalidade de tutela administrativa.

As principais funções do Fundo de Garantia de Depósitos e Proteção Bancária são: 
- Garantir os depósitos feitos em bancos públicos e instituições financeiras regulamentadas pela Lei;

- Prestar auxílio financeiro para restaurar a liquidez e solvência dos bancos e instituições financeiras regulamentadas pela Lei;

- Exercer a função de mediador, em caso de liquidação de bancos e instituições financeiras regulamentadas.

Segundo Marino (2006), a definição da estrutura de funcionamento do FOGADE é regulamentada pelo artigo 282 da Lei Geral dos Bancos. Esta lei define que o Fundo terá uma Assembléia Geral, a qual é composta por:

- O ministro das Finanças, o qual presidirá a Assembléia;

- O presidente do Banco Central da Venezuela;

- O diretor-executivo do Conselho Superior;

- O presidente do Conselho Nacional dos Bancos.

Da mesma forma, o artigo 286 da Lei supracitada prevê que a Junta Diretiva é o órgão máximo de direção e administração do Fundo de Garantia de Depósitos e Proteção Bancária, o qual é composto por um presidente e quatro diretores principais com seus respectivos suplentes.

O presidente, os quatro diretores e seus suplentes, são nomeados pelo Presidente da República. Um dos diretores, juntamente com seu suplente, será escolhido de uma lista com indicações fornecidas pelo Conselho Nacional do Bancário. Os nomes contidos nessa lista não poderão se de funcionários públicos, conforme estabelecido no artigo 287 da Lei Geral dos Bancos.

O FOGADE, assim como o Banco Central da Venezuela, não tem fins lucrativos, não podendo por outro lado, obter perdas patrimoniais, como conseqüência do exercício de suas funções. Por este motivo, nos casos em que o Fundo adquire o controle acionário de um banco ou outra instituição financeira deverá vender as ações correspondentes por meio de oferta pública. 


\subsection{Os programas sociais do governo venezuelano}

Para Bazó (2005), o Estado é responsável pela produção e gestão da ação pública e política social, e é inerente às suas funções de administração pública e de auto-gestão da política pública servir à população.

O Estado é responsável por regular, organizar e criar ferramentas para resolver problemas sociais nas diversas áreas, tais como saúde, habitação, segurança social, educação e assistência social.

Sob essa perspectiva, uma das principais funções do Estado é a intervenção por meio de políticas públicas, ou seja executar ações que tenham como objetivo atenuar os problemas que surgem na sociedade e fornecer soluções que os cidadãos por si só não sejam capaz de buscar.

As politicas públicas são implementadas por meio de políticas socias, muitas vezes voltadas para a população por meio de programas.

Ao contrário do Brasil, a Venezuela não utiliza um banco comercial público como ferramenta de distribuição dos programas socias para a população. O governo venezuelano utiliza órgãos do próprio governo, bem como bancos específicos para este fim, como veremos a seguir.

\subsubsection{Programas sociais realizados com o excedente da renda da PDVA}

A Venezuela é um grande produtor de petróleo. Sua economia é guiada principalmente pela exportação do mesmo. Girardi (2009) afirma que o petróleo é responsável por $94 \%$ da economia venezuelana.

Segundo Girardi (2009) desde 2003, o governo do presidente Hugo Chávez usa excedentes da renda do petróleo obtidos pela companhia Petróleos de Venezuela S.A. - a PDVA - a qual é uma estatal venezuelana responsável pela exploração, produção e comercialização de petróleo - para a realização de programas sociais.

Uma das medidas foi a construção de pequenas clínicas de saúde instaladas principalmente no interior da Venezuela. Nessas clínicas há o 
apoio de Cuba, a qual enviou cerca de quinze mil médicos que atuam em equipes de atendimento familiar nas regiões mais pobres nas periferias das grandes cidades. O governo cubano enviou médicos para as equipes dessas unidades médicas venezuelanas em troca de petróleo mais barato para o país, é o que afirma Girardi (2009).

No tocante à educação, o governo Chávez ampliou o sistema educacional promovendo a abertura de universidades públicas para garantir educação de nível superior e gratuita para os mais pobres. Além disso, lançou o programa "missões" para alfabetizar os adultos, programa que, segundo Girardi (2009), erradicou o analfabetismo no país.

Outro programa oficial subsidiado pela companhia estatal de petróleo é o dos supermercados que vendem mercadorias a preços inferiores para a população mais carente.

\subsubsection{O Banco Del Pueblo Soberano}

Serrano (2005) afirma que a Venezuela passa por uma crise econômica. Por este motivo, uma parte significativa da população não tem conseguido acesso ao mercado formal. Muitos desses cidadãos possuem mão de obra qualificada, mas devido à grande oferta de mão de obra no país, muitos não conseguem um emprego. Alguns desses trabalhadores criaram então suas microempresas para se sustentarem.

Por este fator, o governo venezuelano viu a necessidade de implantar políticas públicas de apoio ao microempresário. Ele criou, portanto, - Banco Del Pueblo Soberano, o qual foi implantado para beneficiar homens e mulheres com baixos rendimentos, incluindo os autônomos.

Os créditos oferecidos pelo governo por meio do Banco Del Pueblo são oferecidos individualmente ou para um grupo. Para obter o empréstimo, o microempresário deve apresentar um projeto contendo os seguintes elementos: estudo de viabilidade econômica, pesquisa de mercado, descrição das etapas do projeto, o montante dos investimentos discriminados e plano de negócios. 
Estes documentos são exigidos para o Banco del Pueblo Soberano avaliar a viabilidade econômica do negócio oferecido por aquela microempresa.

Por meio desses financiamentos, o governo fomenta a criação de novas microempresas, viabilizando a implantação das mesmas, gerando empregos, bem como o crescimento econômico do país.

\subsection{Programa de Financiamento Habitacional Venezuelano}

Diante do cenário econômico apresentado atualmente pela Venezuela, com índice estimado de 25,1\% de inflação em 2009, segundo Girardi (2009), este país possui um sistema de financiamento habitacional debilitado.

Somente em 2008, conforme afirma Mander (2008), a Venezuela por meio de um decreto de lei passou a permitir aos bancos oferecer $100 \%$ de financiamento para compradores de imóveis.

Apesar dessa medida, há escassez de fontes de financiamento, o que limita os empréstimos.

Segundo Mander (2008), quando o atual presidente da Venezuela, Hugo Chavéz, assumiu o posto em 1998, o déficit habitacional da Venezuela era estimado em cerca de um milhão de moradias. Atualmente este déficit ultrapassa 1,8 milhões. Para cobrir o déficit em quinze anos, o autor estima que cerca de duzentos e cinquenta mil moradias precisariam ser construídas a cada ano, dado o crescimento populacional.

Para cobrir esta defasagem, o governo venezuelano vem buscando incrementar o programa de financiamento habitacional, até mesmo estabelecendo parcerias com governos de outros países.

Atualmente o Banco da Venezuela, o banco estatal do país, fornece uma linha de crédito chamado credihipotecário para a população. Nesta linha, o cidadão venezuelano poderá financiar o seu primeiro imóvel com destinação exclusiva de moradia. O imóvel não pode ser destinado para 
uso comercial ou mesmo ser o segundo imóvel habitacional do cidadão que deseja o financiamento.

O financiamento possui regras diferenciadas para cidadãos com renda de até sete mil bolívares, o que atualmente equivale a um mil e seiscentos e dez dólares, com prazo máximo de trinta anos e taxa de juros reduzida.

Segue abaixo uma tabela contendo os parâmetros máximos para financiamento de imóvel pelo banco estatal.

Tabela 4 - Parâmetros de financiamento habitacional do Banco da

Venezuela

\begin{tabular}{|l|c|c|c|c|c|}
\hline & \multicolumn{5}{|c|}{ Faixa de Renda Mensal em BsF } \\
\cline { 2 - 6 } & $\begin{array}{c}\text { De 00 a } \\
2.800,00\end{array}$ & $\begin{array}{c}\text { De } \\
2.800,01 \mathrm{a} \\
5.474,00\end{array}$ & $\begin{array}{c}5.474,01 \mathrm{a} \\
7.000,00\end{array}$ & $\begin{array}{c}\mathrm{De} \\
7.000,01 \mathrm{a} \\
10.120,00\end{array}$ & $\begin{array}{c}10.120,01 \mathrm{a} \\
16.560,00\end{array}$ \\
\hline \% Taxa de Juros & $4,66 \%$ & $6,61 \%$ & $8,55 \%$ & $10,50 \%$ & $12,44 \%$ \\
\hline $\begin{array}{l}\text { \% Comprometimento da } \\
\text { renda mensal }\end{array}$ & $20,00 \%$ & $25,00 \%$ & $30,00 \%$ & $30,00 \%$ & $30,00 \%$ \\
\hline $\begin{array}{l}\text { Tempo máximo de } \\
\text { financiamento }\end{array}$ & 30 anos & 30 anos & 30 anos & 25 anos & 25 anos \\
\hline Limite de crédito em BsF & $\begin{array}{c}108.477,4 \\
5\end{array}$ & $214.055,74$ & $\begin{array}{c}271.858,8 \\
0\end{array}$ & $\begin{array}{c}321.548,2 \\
5\end{array}$ & $457.509,38$ \\
\hline
\end{tabular}

\subsection{A Venezuela e o Mercosul}

Segundo Saraiva; Ruiz (2009), a recente entrada da Venezuela como membro pleno do Mercosul é resultado de um processo que se iniciou em meados dos anos 90, quando o governo de Rafael Caldera começou a redefinir a estratégia de integração do país no contexto de uma revisão de sua política externa.

Saraiva ; Ruiz (2009) afirmam que a política externa dos governos venezuelanos entre 1958 e 1998 esteve delimitada pela condição de país ocidental democrático e petroleiro, que começou a receber importantes recursos desde o primeiro boom do petróleo da década de 1970. Estes 
fatores determinaram as prioridades geográficas de sua política externa, na qual os Estados Unidos apareciam como um parceiro natural na defesa da democracia e com o qual a Venezuela podia partilhar uma estratégia assistencialista no Caribe com vistas a evitar a expansão do comunismo. Por outro lado, poderia-se considerar que o petróleo era um instrumento que permitia à Venezuela ampliar sua estratégia internacional e apostar em uma maior independência frente aos Estados Unidos.

Para Saraiva ; Ruiz (2009), no período entre 1999 e 2001, já com Hugo Chavéz no poder, as tendências existentes no chavismo trataram de influir na política externa. Os militares nacionalistas e os pragmáticos, embora apoiassem objetivos de promoção da ordem multipolar, integração latino-americana e cooperação sul-sul, foram cautelosos em evitar promover um conflito com os Estados Unidos. Os radicais, por sua vez, favoreceram uma política externa mais militante, especialmente no que diz respeito à natureza estratégica da integração. Até 2002, nenhum dos setores tinha uma posição hegemônica no desenho e na aplicação da política de integração.

Desde o final de 2001 o cenário foi se delimitando com mais clareza. Neste ano, um grupo dos nacionalistas bolivarianos, movimentos políticos como o MAS e setores empresariais distanciaram-se do governo. O setor radical do chavismo começa a se impor, incrementando-se a crítica à ordem mundial e distanciando-se dos Estados Unidos. A partir de 2003 Chávez declara seu governo como anti-imperialista e se propõe a desenvolver um projeto político descrito como Socialismo do Século XXI.

Este processo de definição e redefinição da estratégia internacional de Venezuela manifestou-se em sua política de integração regional. Nos primeiros anos, o Presidente Chávez insistia na criação uma Confederação Latino-Americana, que deveria ter um conteúdo majoritariamente político, e criticava a proposta de criação da Alca.

Saraiva ; Ruiz (2009) afirmam que a partir de 2001 anunciava-se a Iniciativa Bolivariana para as Américas (Alba), embora tenha sido somente a partir de 2003 que se começou a delimitar o conteúdo da proposta. A partir de 2004 torna-se clara a estratégia de integração do governo venezuelano, 
que começa a refletir as reações anti-neoliberais e antinorte-americanas dos grupos radicais. A ascensão de governos de esquerda no Brasil, Argentina e Uruguai e a decisão dos países andinos de negociar um tratado bilateral de livre comércio com os Estados Unidos determinaram duas decisões fundamentais que implicaram em uma mudança na estratégia de integração da Venezuela: a sua saída da Comunidade Andina e a solicitação de entrada como membro pleno no Mercosul.

Segundo Barbosa (2008), primeiramente, a Venezuela, em outubro de 2005, solicitou formalmente sua inclusão como membro pleno do Mercosul e, em dezembro, os países-membros assinaram um acordo-marco nesse sentido. Em julho de 2006, foi assinado o Protocolo de Adesão, que deverá entrar em vigor após sua aprovação pelos Congressos dos quatro países-membros e pelo Congresso venezuelano.

Em dezembro de 2009, o senado brasileiro aprovou a entrada do país no bloco econômico. Argentina e Uruguai já haviam se manifestado favoravelmente. A Venezuela, aguarda portanto, somente o parecer do Paraguai para tornar-se membro efetivo do Mercosul. 


\section{CAPÍTULO 3 - A RELAÇÃO ENTRE BRASIL E VENEZUELA}

Nos capítulos anteriores discorremos sobre o sistema bancário brasileiro e venezuelano, bem como sobre os programas socias do governo desses países e sobre a participação dos mesmos no Mercosul.

Neste capítulo analisaremos a relação existente entre os dois países, bem como faremos uma análise de uma entrevista fornecida pelo gerente regional internacional da Caixa Econômica Federal do escritório internacional da Venezuela.

Primeiramente analisaremos as caractereísticas da política externa do governo Lula, atual presidente do Brasil, e do governo de Hugo Chavez, atual presidente da Venezuela. Em seguida, faremos uma análise do sistema bancário dos dois países e posteriormente analisaremos os interesses da Caixa Econômica Federal e, consequentemente, do governo brasileiro na Venezuela.

\subsection{Política externa voltada para o Mercosul}

Segundo Barbosa (2008), a projeção externa do Brasil cresceu e consolidou-se nos últimos quinze anos, com a natural ampliação de sua agenda externa, tanto econômica como politicamente. Além disso, o país passou a ter uma atuação mais desinibida.

A crescente projeção externa do Brasil não seria possível sem a estabilização da economia e a continuidade dada pelo governo Lula à política econômica do governo FHC. Do ângulo político, ajudou também o fato de um candidato do Partido dos Trabalhadores (PT), percebido inicialmente como radical, ter sido eleito para a presidência do Brasil e ter se revelado um moderado. Lula demonstrou que a esquerda por ele representada, eleita democraticamente, pode ser uma alternativa ao populismo de esquerda para os países da América do Sul. A multiplicação dos exemplos de presença e da ação do Brasil mostra que a atuação brasileira transcende significativamente o âmbito regional. 
Barbosa (2008) afirma que a América do Sul representa o espaço territorial onde o peso específico do Brasil é preponderante sob qualquer critério, seja o território, a população, os recursos naturais, a indústria ou o avanço tecnológico.

Nenhum país, por mais poderoso que seja e mais globalizada a sua economia, pode deixar de dar atenção à sua vizinhança por razões somente de parceria comercial, mas, sobretudo, por uma questão de exigência política. Somente desse modo será capaz de acompanhar e entender as transformações regionais que afetam seus interesses. $\mathrm{Na}$ política externa se deve sempre levar em consideração as circunstâncias conjunturais e permanentes tanto no Brasil como nos países da região.

A ideologização das decisões e a politização das negociações comerciais, características que moldam as prioridades da política externa do atual governo brasileiro, também se refletem na ação diplomática do Itamaraty na América do Sul.

O mapa político e o cenário econômico na América do Sul estão sob profundas transformações. A emergência de movimentos sociais, do poder indígena e de novas lideranças fez ressurgir como foco principal um acentuado apelo popular nacionalista, antiglobalizante e de forte viés antiamericano, cujo epicentro são os países andinos, especialmente a Venezuela. No entanto, os efeitos ideológicos do fenômeno político em questão transbordam as fronteiras dos países mencionados.

De modo geral, a política externa do atual governo para a região não trouxe inovações, visto que todos os governos nos últimos vinte anos atribuíram grande prioridade à América do Sul e ao processo de integração regional. No governo Lula, o que mudou foi a maior ênfase dada aos objetivos tradicionais e a forma pela qual o Brasil interage com seu entorno geográfico.

A prioridade declarada pela região e pela integração regional é uma das principais linhas de atuação do Itamaraty nos dois governos Lula. $O$ discurso oficial proclama a América do Sul como a primeira preocupação da política externa e não se cansa de repetir que nunca na história do Brasil o 
relacionamento com os países da região foi tão próximo e tão positivo, não só em termos de relação bilateral como também em termos de integração regional, em especial no Mercosul.

No inicio do primeiro mandato, o atual governo procurou atuar de forma proativa, não escondendo sua intenção de exercer uma liderança efetiva, base para uma estratégia de poder regional, que projetaria o país no exterior. Em virtude da reação negativa que essa atitude despertou na vizinhança e do ativismo cada vez mais incômodo de Hugo Chávez, o governo brasileiro modificou seu discurso público, sem, no entanto, abandonar o papel protagônico da política externa sul-americana. Agora, apresenta-se como um fator de equilíbrio e moderação para a região.

Para Barbosa (2008), o governo Lula manteve-se como interlocutor da Venezuela, dadas as afinidades ideológicas e a leitura que faz da atual situação política e econômica de alguns dos vizinhos, apesar da agenda diferente desse país e, em muitos casos, contrária aos interesses nacionais.

Barbosa afirma que o Palácio do Planalto considera o presidente Hugo Chávez um dos responsáveis pela construção de um novo equilíbrio político e de uma nova estabilidade na região andina. Para os estrategistas do Planalto, longe de serem fatores de instabilidade, são, antes, a possibilidade real de uma nova estabilidade, fundada, não na desigualdade e na iniqüidade sociais ou na submissão externa, mas na soberania nacional e popular. Essa leitura, que permite entender as formulações mais gerais e as manifestações práticas da atual política externa brasileira, choca-se dramaticamente com a realidade dos acontecimentos que envolvem a Venezuela.

A partir de meados de 2007, o governo brasileiro passou a oferecer aos países vizinhos fundos compensatórios para corrigir as assimetrias estruturais, perdão de dívida, investimentos, sobretudo da Petrobrás, e financiamento, em especial do BNDES, e outras facilidades políticas e comerciais. As delicadas relações bilaterais com a Venezuela são 
conduzidas com declaradas mostras de compreensão e generosidade da parte do Brasil.

Para Barbosa (2008), a atual política externa brasileira passou a dar mais ênfase ao relacionamento bilateral com projetos de cooperação, em diversas áreas, com cada um dos vizinhos, deixando para um segundo plano os esforços de integração regional, apesar de a retórica oficial seguir pretensamente nesse sentido. Isso se deve, provavelmente, às frustrações registradas com a efêmera experiência da Comunidade Sul-Americana de Nações (Casa), que a diplomacia brasileira esforçou-se por promover e que contou com a indiferença dos demais parceiros do Mercosul, bem como à difícil concretização da União de Nações Sul-Americanas (Unasul), patrocinada por Chávez.

A atual política externa pretende que o Brasil, sendo o maior e mais rico país da região, tome a dianteira nas políticas de integração, faça concessões aos países menores e assuma a responsabilidade de reduzir as assimetrias estruturais existentes, difíceis de serem superadas.

O presidente Lula resumiu, durante a reunião de presidentes do Mercosul em Montevidéu, em dezembro de 2007, as frustrações do governo brasileiro com a lentidão no processo de tomada de decisões e com as razões alegadas para as dificuldades por que passa o Mercosul. Com propriedade e concordando com os críticos do funcionamento das instituições do Mercosul, Lula disse que o Mercosul tem inimigos internos e externos. Os inimigos internos, segundo o Presidente, são o corpo técnico e burocrático dentro dos governos dos países membros. Nesse contexto, mencionou as decisões de investimento adotadas na Bolívia e na Venezuela, que não tinham apoio técnico da Petrobrás. Para o presidente, os inimigos externos são os que sonham em vender tudo para os EUA e a União Européia.

Em que pesem as ressalvas do presidente Lula, o discurso oficial registra a grande intensificação do diálogo político, econômico e comercial. O Mercosul ocupa, a exemplo dos governos anteriores, um lugar de relevo 
na política externa do governo atual e é a base da estratégia visando a fortalecer uma união política e econômica da América do Sul.

No tocante à Venezuela, a sua entrada no Mercosul deverá ter impacto sobre a futura dinâmica do bloco, pois o ingresso deste país como membro pleno poderá modificar a lógica do processo de integração, assim como enfraquecer o eixo Brasil-Argentina.

Barbosa (2008) afirma que a decisão de entrada da Venezuela no bloco foi tomada mais por considerações políticas do que econômicas e comerciais. Para ele, se levada a cabo da forma como prescreve o Tratado de Assunção, ampliará em 14\% o PIB do Mercosul e reforçará a posição dos países-membros no campo energético. A Venezuela não mudará o perfil econômico do Mercosul, mas passará a influir nas agendas temáticas e setoriais.

Do ponto de vista do interesse brasileiro, é positiva a inclusão no Mercosul de um país com um grande mercado para os produtos e serviços brasileiros como a Venezuela. O intercâmbio comercial bilateral está crescendo, tendo, segundo Barbosa (2008) alcançado mais de U\$ 4,5 bilhões em 2007, com um superávit brasileiro de cerca de U\$ 4 bilhões. $O$ Brasil ocupa hoje um lugar de destaque como prestador de serviços, especialmente no setor de grandes projetos de infra-estrutura. Desde 2007, - Brasil passou a ser o segundo sócio comercial do país, ficando atrás somente dos Estados Unidos, principal consumidor do petróleo venezuelano. A Venezuela importa $70 \%$ do que consome, a maior parte da Colômbia e dos Estados Unidos. A sua entrada no bloco estenderia o mesmo para o norte da América do Sul, com influência na região caribenha, trazendo assim, benefícios para os Estados da região norte do Brasil.

Nas relações com a Venezuela de Hugo Chávez, o governo Lula tem mantido a política do governo anterior no sentido de evitar o isolamento e uma eventual confrontação com Caracas, sempre procurando uma aproximação mais efetiva. De concreto, as conversações da Petrobrás com a Petróleos de Venezuela S.A. (PDVSA) não avançam. 
O ingresso da Venezuela ou de qualquer outro país no Mercosul, pela complexidade, pelas implicações institucionais e pelas negociações de acordos comerciais com outros países, deveria ser objeto, inicialmente, de uma análise isenta e objetiva, deixando de lado considerações de ordem política ou ideológica. $\mathrm{O}$ artigo 20 do Tratado de Assunção, que criou o Mercosul, prevê que todos os países-membros da Aladi podem solicitar adesão ao bloco, como fez a Venezuela. $\mathrm{O}$ artigo 2 do Tratado define que um dos fundamentos do Mercosul é justamente o princípio da reciprocidade de direitos e obrigações entre os Estados-Partes.

Segundo os termos do Protocolo aprovado pelos cinco países, a Venezuela adotará os protocolos, decisões e resoluções do Mercosul de forma gradual, no mais tardar em quatro anos contados a partir da entrada em vigência do Protocolo (artigo 3). A Nomenclatura Comum do Mercosul e a Tarifa Externa Comum (TEC), no mais tardar em quatro anos (artigo 4). As partes comprometem-se a alcançar o livre-comércio, no caso do Brasil e da Argentina até janeiro de 2012, no caso do Paraguai e Uruguai até 2013 e no caso da Venezuela (em relação aos membros do Mercosul) até 2012.

\subsection{O sistema bancário do Brasil e da Venezuela}

O sistema bancário brasileiro é um dos mais avançados e rentáveis do mundo. Por este motivo, é um sistema muito visado por outros países.

Por meio da Caixa Econômica Federal, único banco brasileiro de capital 100\% público, o país vem estreitando negócios nesse ramo com a Venezuela.

A Venezuela, por outro lado, possui um sistema bancário debilitado. Em 2009, o governo venezuelano nacionalizou o Banco da Venezuela, o qual pertencia ao grupo Santander, passando a controlar $25 \%$ do setor bancário do país.

Em janeiro de 2009, segundo a Agência Brasileira de Desenvolvimento Industrial (2009), os presidentes Hugo Chávez e Luiz 
Inácio Lula da Silva se reuniram na Venezuela, dando continuidade às reuniões presidenciais trimestrais iniciadas em dezembro de 2007. O encontro permitiu revisar os ganhos do ano de 2008 e delinear as ações bilaterais para o ano de 2009 e 2010.

Um dos objetivos da reunião foi aprofundar os trabalhos de cooperação na área habitacional e de desenvolvimento urbano entre os países. Para tanto, deverão intensificar o intercâmbio de conhecimentos com o objetivo de:

1 - Promover a urbanização de favelas de maneira integrada a ações sociais sustentáveis, mediante a participação comunitária, a capacitação profissional e a geração de emprego e renda;

II - Aperfeiçoar a cooperação nas áreas de capacitação, assistência técnica e desenvolvimento de fundos para financiamento habitacional e de infra-estrutura.

Nesse sentido, encontros técnicos no Brasil e na Venezuela foram realizados no primeiro bimestre de 2009, para tratar dos seguintes temas: urbanização de favelas, registro social e bancário, assistência técnica e capacitação, administração de fundos, modalidades de financiamento e sistemas de gestão da informação.

No encontro, os Presidentes dos dois países decidiram ampliar o escopo da cooperação relativa ao acesso a serviços bancários, ao designar o Ministério do Poder Popular para a Economia e Finanças, pelo lado venezuelano, e a Caixa Econômica Federal, pelo lado brasileiro, para assinar instrumentos específicos, tendo em conta a necessidade de ampliar e priorizar a cobertura, em escala nacional, da rede bancária pública, constituindo na Venezuela:

I - Redes de atenção à população que necessita de acesso a serviços bancários e programas sociais;

II - Soluções tecnológicas de apoio à universalização do acesso a serviços bancários e programas sociais.

Em entrevista a jornais sobre o assunto, o presidente Hugo Chavéz declarou ter interesse em transformar o Banco da Venezuela em 
uma versão local da Caixa Econômica Federal. O banco brasileiro inaugurou um escritório de representação naquele país no mesmo ano com a finalidade de dar apoio ao governo venezuelano e com a finalidade de ampliar os termos acordados na cooperação.

A Caixa Econômica Federal é o banco do governo. Além de controlar e efetuar pagamento de todos os programas sociais do governo brasileiro, o banco é líder em financiamento habitacional no país. Estas características atraíram o governo venezuelano, o qual almeja implantar o modelo no país.

Em parceria com o escritório internacional da Caixa localizado em Caracas, o governo venezuelano lançará o Plano de Desenvolvimento Sustentável para as Favelas de Caracas. O banco brasileiro fornecerá apoio técnico ao governo de Hugo Chavéz. Para tanto, o banco assinou um acordo de cooperação técnica com o governo da Venezuela, a fim de prestar apoio ao governo venezuelano em projetos de inclusão bancária, urbanização de comunidades e ações sociais sustentáveis, desenvolvimento urbano e financiamento habitacional.

No acordo de cooperação técnica celebrado entre a Caixa e o governo venezuelano não consta o financiamento de residências no país andino, mas sim o repasse dos modelos, para o governo venezuelano, que 0 banco usa no Brasil para financiar casas populares.

Recentemente o governo brasileiro, em parceria com a Caixa Econômica, lançou o programa de financiamento habitacional Minha Casa Minha Vida, o qual oferece subsídios para famílias com renda mais baixas, e que irão financiar imóveis que ainda não foram habitados.

Este modelo deve ser repassado ao governo venezuelano por meio do banco público brasileiro, pois a Venezuela apresenta alto índice de déficit de moradias, bem como uma alta taxa de desemprego.

Com o programa, o governo brasileiro não somente visa diminuir o déficit de moradias no país, como também tem a intenção de gerar emprego no setor de construção civil. Igualmente, o governo venezuelano tem o mesmo objetivo. 
O banco brasileiro, conforme já citado, é o gestor dos programas sociais do governo, tais como bolsa família, bolsa escola e bolsa atleta, característica que também atraiu o governo venezuelano, o qual almeja implantar sistema semelhante no país.

O governo da Venezuela possui vários programas sociais, porém o mesmo não utiliza seu banco estatal, o Banco da Venezuela, para gerir tais programas. Seu objetivo é implantar um modelo semelhante ao realizado pelo governo brasileiro, o qual utiliza a Caixa Econômica com este fim.

\subsection{Análise da entrevista realizada com o gerente do escritório internacional da Caixa Econômica Federal na Venezuela}

Inaugurado em outubro de 2009, o Escritório Regional da Caixa Econômica Federal conta com dois colaboradores expatriados do Brasil, os quais são um superintendente regional internacional e um gerente regional internacional.

O escritório localizado em Caracas é o terceiro escritório de representação internacional do banco, dando continuidade à internacionalização do banco público brasileiro. Os outros escritórios se localizam nos Estados Unidos da América e no Japão.

O escritório da Venezuela possui uma característica diferenciada dos outros dois escritórios, a qual foi relatada pelo gerente regional Samuel de Freitas Junior em entrevista fornecida à autora desta monografia no dia 24 de fevereiro de 2010 na Matriz no banco, localizada em Brasília.

A entrevista, constante como anexo na página 51 deste trabalho, foi composta de cinco perguntas, as quais visavam buscar informações para respaldar os dados constantes no corpo desse trabalho.

Nas páginas seguintes transcreveremos as respostas fornecidas pelo gerente às cinco perguntas a ele questionadas, bem como as analisaremos. 


\subsubsection{Objetivo da Caixa em abrir o escritório internacional na Venezuela}

Ao ser questionado sobre o objetivo da Caixa Econômica em abrir um escritório internacional na Venezuela, o gerente Samuel disse que a Caixa quer principalmente priorizar negócios no âmbito do Mercosul. Ele afirmou que a abertura também se deve ao apoio à política internacional do governo federal.

$\mathrm{Na}$ entrevista, o gerente afirmou que a abertura do escritório no país andino manterá a estratégia da Caixa de captar o envio de remessas para o país, mas difere da estratégia dos outros escritórios internacionais do banco porque também visa o comércio exterior, principalmente com o MERCOSUL.

Como vimos nas páginas anteriores o governo brasileiro tem priorizado a América do Sul em sua política externa. A Caixa foi, portanto, um dos veículos utilizados pelo governo para facilitar os trâmites, tais como envio de remessas ao Brasil, pelas micro e pequenas empresas que atuam nos países vizinhos, principalmente na Venezuela e no âmbito do Mercosul.

O gerente também afirmou que a Caixa levará benefícios para a Venezuela atuando principalmente em desenvolvimento urbano e habitacional naquele país.

Conforme relatado nas páginas anteriores a Venezuela apresenta alto índice de déficit de moradia. A Caixa auxiliará o governo venezuelano transmitindo a ele o conhecimento que o banco possui em urbanização de favelas e acesso à moradia pela população mais carente.

Essa parceria beneficiará tanto o Brasil, quanto à Venezuela, pois há pontos positivos para ambos os países. O Brasil será beneficiado pela facilidade de envio de remessas para o país, aumentando o giro de capital no mesmo. A instalação do escritório da Caixa também facilitará os trâmites de empresas que atuam no mercado Venezuelano. A Venezuela se beneficiará, pois terá auxílio para alcançar seu objetivo de diminuir o déficit habitacional do país, conforme veremos a seguir. 


\subsubsection{Benefícios para Venezuela devido à implantação do escritório da Caixa Econômica}

Quando questionado sobre os benefícios que a Venezuela terá com a abertura do escritório internacional do banco brasileiro, o gerente afirmou que inicialmente o país se beneficiará com a cooperação técnica que - Brasil tem a oferecer. Ele afirmou que o banco público brasileiro é experiente em desenvolvimento urbano. A Caixa transmitirá esses conhecimentos para o governo venezuelano, auxiliando-o na urbanização das favelas de Caracas. A Caixa também oferecerá conhecimentos de bancarização para a população, auxiliando o governo na implantação do sistema de correspondente bancário no país.

Tanto o Brasil quanto a Venezuela terão benefícios nessa parceria.

\subsubsection{A abertura do escritório internacional da Caixa e a participação da Venezuela no Mercosul}

Ao ser indagado se a abertura do escritório internacional da Caixa Econômica Federal teria facilitado a aprovação da Venezuela como país membro do Mercosul pelo Senado Federal brasileiro, o gerente da Caixa disse que a instalação do escritório do banco em Caracas ajudou na decisão do Senado, mas não foi o motivo principal. Para ele, a aceitação da entrada da Venezuela no Mercosul tem mais relação com a ação do governo federal e do Itamaraty. Segundo ele, a Caixa é um instrumento do governo, mas a atuação em temas relacionados ao Mercosul é do Ministério das Relações Exteriores. A Caixa estreitou o relacionamento entre os dois países, o que facilitou o trâmite no Senado Federal.

Diante do que fora relatado pelo entrevistado e dos argumentos apresentados neste trabalho acadêmico, observamos que com a instalação do escritório de representação da Caixa Econômica a Venezuela terá mais suporte para reduzir o déficit habitacional no país, melhorando, assim, a 
qualidade de vida de seus cidadãos. O Brasil, juntamente com a Caixa, vislumbra um auxílio às empresas que forem realizar comércio com o país andino, porém a implantação do escritório do banco na Venezuela não teve relação direta com a aceitação, pelo governo brasileiro, da entrada do país no Mercosul.

\subsubsection{A Venezuela e o Mercosul}

Ao ser questionado sobre a participação da Venezuela no Mercosul, o gerente do escritório internacional da Caixa Econômica respondeu que em sua opinião a participação da Venezuela é positiva. Para ele, o Mercosul necessita de fatos novos e a Venezuela trará estes fatos para o bloco.

Samuel afirmou que a Venezuela prioriza a política externa para a América do Sul, assim como o Brasil. "Nem todos os países parceiros tem essa prioridade, logo tanto o Brasil quanto a Venezuela tem a lucrar", acrescentou o gerente. Para ele, a participação da Venezuela no Mercosul irá fortalecer o bloco e a América do Sul como um todo.

Diante do relato do gerente da Caixa e dos dados apresentados neste trabalho, afirmamos que a participação da Venezuela no Mercosul será positiva e é de grande interesse do Brasil, pois a política externa de ambos os países prioriza a América do Sul. Além disso, há um vasto mercado consumidor para os produtos brasileiros na Venezuela. O Brasil também passará a ter mais acesso à energia, pois a Venezuela é um país produtor de petróleo.

A participação efetiva desse país no bloco trará, portanto muitos benefícios ao Brasil.

\subsubsection{Política internacional adotada pelo governo Lula}

Os escritórios internacionais de representação da Caixa Econômica Federal localizados no exterior foram abertos durante o governo 
do presidente Luis Inácio Lula da Silva. Ao ser indagado se a política internacional adotada pelo governo do Presidente teria relação com a inauguração dos escritórios, Samuel afirmou haver tal relação.

Ele relatou que os escritórios internacionais da Caixa começaram a ser inaugurados entre os anos de 2003 e 2004. Primeiramente foi implantado o escritório dos Estados Unidos da América e em seguida o do Japão.

Em outubro de 2009 houve a abertura oficial do escritório internacional de representação da Caixa Econômica na Venezuela. Samuel afirmou que, o trâmite de abertura se iniciou de acordo com dois eixos de atuação do governo federal.

O primeiro eixo vai ao encontro do objetivo principal do governo com os emigrantes brasileiros. "A Caixa é um banco popular e os emigrantes do país precisavam de um canal para enviar remessas aos seus familiares que se encontram no Brasil. Como a Caixa atinge a faixa da população de baixa renda, a abertura dos escritórios facilita o envio de numerário a um maior número de clientes e consequentemente atinge uma maior quantidade de cidadãos brasileiros", afirmou o gerente.

O segundo eixo foi traçado baseado na política de cooperação técnica do país. Com a implantação do escritório na Venezuela o Brasil passa a contar com mais um instrumento de remessa de valores para o país e não depende mais dos bancos estrangeiros.

O gerente afirmou que a Caixa é um banco público e consequentemente muito forte. $\mathrm{Na}$ opinião dele, muitos países se sentem seguros em realizar negócios com o banco. Por este motivo, a Venezuela permitiu a abertura do escritório de representação em Caracas.

Samuel relatou que a Caixa, assim como o governo brasileiro, defende a política de incentivo às micro e pequenas empresas. $O$ banco possui muitos clientes com esse perfil, já o governo tem grande interesse em incentivar o crescimento dessas empresas.

A atuação de empresas pequenas é muito crescente no Mercosul, conforme relatado pelo gerente Samuel. 
Ao basearmos nos relatos do gerente da Caixa, percebemos que a Caixa Econômica tem interesse em captar clientes que visam o comércio exterior, o que ratifica a política exterior do governo brasileiro.

A parceria entre o banco público brasileiro e o governo venezuelano será benéfica. A abertura do escritório internacional não foi o motivo para a aceitação do país no Mercosul, no entanto o Brasil terá muitos benefícios. 


\section{CONCLUSÃO}

Durante os estudos deste trabalho foram analisadas características do sistema bancário do Brasil e da Venezuela, bem como dos programas sociais realizados pelo governo de ambos os países e da participação dos mesmos no bloco econômico Mercosul.

Podemos perceber que o sistema bancário brasileiro é um dos mais avançados e rentáveis do mundo, apresentando capacidade de enfrentar os desafios do financiamento do desenvolvimento do Brasil. $O$ governo brasileiro utiliza o banco de totalidade de capital público, a Caixa Econômica Federal, para ser o condutor e para realizar o pagamento de seus programas sociais, tais como Bolsa Família, Bolsa Atleta e Bolsa Escola. Além disso, o sistema de financiamento habitacional brasileiro é muito eficiente. A Caixa Econômica detêm a maior fatia da porção desse mercado, sendo o banco líder no setor. Devido a este fator, o governo brasileiro escolheu o seu banco público para ser banco a trabalhar com o programa de incentivo à primeira moradia do cidadão brasileiro, o programa Minha Casa Minha Vida. Por meio do programa, o cidadão de baixa renda pode financiar um imóvel novo, diminuindo assim o déficit de moradia no país e ainda gerando empregos no setor de construção civil.

Todas essas características atraíram os olhares do governo venezuelano, o qual estabeleceu uma parceria com a Caixa Econômica Federal, que inaugurou um escritório de representação do banco em Caracas, a capital venezuelana, em outubro de 2009.

Com o acordo de cooperação técnica assinado entre o banco público brasileiro e o governo de Hugo Chavéz, a Venezuela passa a contar com o apoio do banco para auxiliá-lo em assuntos de soluções tecnológicas de apoio à universalização do acesso a serviços bancários e programas sociais, além de receber o conhecimento que o banco possui em financiamento habitacional à população de baixa renda.

Concluimos que essa parceria é lucrativa para a Venezuela, pois o objetivo inicial da Caixa é promover a urbanização de favelas de maneira 
integrada a ações sociais sustentáveis, mediante a participação comunitária, a capacitação profissional e a geração de emprego e renda, além de aperfeiçoar a cooperação nas áreas de capacitação, assistência técnica e desenvolvimento de fundos para financiamento habitacional e de infraestrutura. Um país que apresenta índice elevado de déficit habitacional tem muito a lucrar com o apoio de um banco de outro país líder no setor. Além disso, o governo venezuelano declarou ter interesse em transformar o Banco da Venezuela em um banco com características parecidas com as da Caixa Econômica. A instalação do escritório internacional de representação do banco brasileiro irá contribuir para o governo da Venezuela atingir tal objetivo.

No tocante ao Mercosul, concluímos que a América do Sul representa o espaço territorial onde o peso específico do Brasil é preponderante sob qualquer critério, seja o território, a população, os recursos naturais, a indústria ou o avanço tecnológico. Por este motivo, o Brasil tem interesse na efetivação da Venezuela como país membro do bloco, pois a política externa do país andino vai ao encontro à política externa do governo brasileiro. Ambos os países priorizam negócios com a América do Sul, característica que nem todos os países do bloco possuem.

Seguindo a linha do pensamento do governo brasileiro, a Caixa Econômica Federal estabeleu uma política de atendimento em seu escritório de representação na Venezuela às micro e pequenas empresas que estabelecem comércio com o país. Os outros dois escritórios internacionais do banco, localizados nos Estados Unidos da América e no Japão, focam somente o envio de remessas para o Brasil. Já o escritório da Venezuela visa o comércio exterior, principalmente com o Mercosul, além de facilitar o envio de numerário ao país, incrementando assim os negócios do banco fora do país.

Apesar de visar negócios no âmbito do Mecorsul, a abertura do escritório internacional da Caixa Econômica na Venezuela não influenciou na aceitação da entrada do país no bloco econômico pelo Senado Federal Brasileiro. Ela pode ter colaborado, porém não foi o motivo principal. Como 
banco público, a Caixa Econômica Federal é um instrumento do governo, no entanto a atuação em temas relacionados ao Mercosul é do Ministério das Relações Exteriores, conforme relatado na entrevista analisada no terceiro capítulo deste trabalho.

Apesar de ter um sistema de financiamento habitacional avançado e de transmitir algumas técnicas para o governo venezuelano utilizando a parceria realizada com Caixa Econômica Federal, este fator tampouco influenciou a aceitação da Venezuela no Mercosul pelo governo brasileiro.

A Venezuela é um mercado consumidor em potencial para produtos brasileiros. Além do mercado consumidor a ser conquistado na Venezuela, com a aceitação deste país como membro no Mercosul, o Brasil passa a ter acesso a recursos de energia, pois a Venezuela é grande produtor de petróleo.

A Venezuela, por outro lado, também tem um vasto mercado a ser trabalhado no campo do Mercosul.

O bloco econômico estava adormecido, necessitando adquirir novas características. Sendo assim, a entrada da Venezuela no Mercosul trará vantagens para o mesmo, possibilitando que o bloco volte a ter força na região.

Com o desenvolvimento dos dados relatados neste trabalho objetivamos contribuir com as pesquisas que serão realizadas futuramente acerca do Mercosul e do sistema bancário dos países estudados: o Brasil e a Venezuela. 


\section{REFERÊNCIAS BIBLIOGRÁFICAS}

Agência Brasileira de Desenvolvimento Industrial. Brasil e Venezuela assim cooperação bilateral para diversas áreas. Revista Fator Brasil. Brasília. Janeiro, 2009. Disponível em: http://www.abdi.com.br/?q=node/1369 Consultado em: 17/03/2010

Barbosa, Rubens. A Política Externa do Brasil para a América do Sul e o Ingresso da Venezuela no Mercosul. Revista Interesse Nacional. Ed. 8. São Paulo. 2008. Disponível em: http://www.interessenacional.com/artigosintegra.asp?cd_artigo=9 Consultado em: 17/03/2010

Bazó, Ruth Matos. Enfoques de evaluación de programas sociales: Análisis comparativo. Revista de Ciencias Sociales. Vol.11. N. II. Marcaibo. Maio, 2005. Disponível em: http://www.scielo.org.ve/scielo.php?script=sci_arttext\& pid=\$1315-95182005000200011\&lng=en\&nrm=isso Consultado em: 15/03/2010.

Caixa Econômica Federal. Balanço Social 2005. Brasília, 2005. 81p.

Caixa Econômica Federal. Balanço Social 2007. Brasília, 2007. 162p.

Chavantes, Walter José. Evoluindo com o Sistema Bancário do Brasil. 2009. Disponível em: http://www.caringi.com.br/aberj/evoluindo3.htm Consultado em: 01/02/2010.

Doellinger, Carlos Von. Sistema Bancário e Desenvolvimento. 2009. Disponível em: http://www.caringi.com.br/aberj/sistemabanc.htm Consultado em: 01/02/2010.

Fortuna, Eduardo. Mercado Financeiro: produtos e serviços. Rio de Janeiro: Qualitymark, 1992. 223p. 
Girardi, Renata. Conheça os programas sociais apoiados por Hugo Chavez. Estadão. Disponível em: http://www.estadao.com.br/noticias/internacional, conheca-os-programas-sociais-apoiados-por-hugo-chavez,323454,0.htm Consultado em: 16/03/2010.

Governo Federal. Minha Casa Minha Vida: Moradia para as famílias, Renda para os trabalhadores, Desenvolvimento para o Brasil. 2009. 40p.

Mander, Benedict. Venezuela permitirá financiamento habitacional intregral. Disponível em: http://economiaparapoetas.wordpress.com/2008/08/19/ venezuela-permitira-financiamento-habitacional-integral/ Consultado em: $16 / 03 / 2010$

Marino, Léger Hector. Sistema Bancário Nacional: Venezuela, março/2006. Disponível em: http://www.monografias.com/trabajos33/sistema-bancariovenezuela/sistema-bancario-venezuela.shtml Consultado em: 15/02/2010

Meirelles, Antonio Chagas. O Real e a Nova Estrutura do Sistema Bancário. 2008. Disponível em: http://www.caringi.com.br/aberj/real2.htm Consultado em: 06/02/2010.

Mendonça, Ana Rosa Ribeiro de. Sistemas Financeiros do Mercosul: estrutura, financiamento de longo prazo e interpenetração de capitais. IE/UNICAMP. 10/2009. Disponível em: http://www.eco.unicamp.br/docdown load/publicações/textosdicussao/textos166.pdf Consultado em: 13/02/2010

Reis, Pamela. Caixa absorveu demanda de outros bancos para atingir patamar histórico na concessão de crédito. PiniWeb, 15/10/2009: Disponível em: $\quad$ http://www.piniweb.com.br/construcao/habitacao/caixa-absorveudemanda-de-outros-bancos-para-atingir-patamar-historico-154093-1.asp Consultado em: 13/02/2010 
Saraiva, Miriam Gomes; Ruiz, José Briceño. Argentina, Brasil e Venezuela: as diferentes percepções sobre a construção do Mercosul. Revista Brasileira de Política Internacional. Volume 52. N. I. Brasília. Jan-Jun/2009. Disponível em: http://www.scielo.br/scielo.php?script=sci_arttext\&pid=\$0034-7329200 9000100008\&lang=pt Consultado em: 16/03/2010

Serrano, Maria Isabel; Borgucci, Emmanuel. Financiamiento otorgado por el Banco del Pueblo a las microempresas zulianas. Revista de Ciencias Sociales. Vol. 11 N. II, Marcaibo, Maio, 2005. Disponível em: http://www.scielo.org.ve/scielo.php?pid=\$1315-95182005000200008\&script =sci_arttext Consultado em: 15/03/2010 


\section{Anexo \\ Entrevista concedia pelo Gerente Regional do Escritório Internacional da Venezuela - Caixa Econômica Federal}

Gerente: Samuel de Freitas Júnior

Entrevista concedida no dia 24/02/2010 na Matriz da Caixa Econômica Federal, Brasília - DF.

1- Qual o objetivo da Caixa em abrir um Escritório Internacional na Venezuela?

O objetivo principal da Caixa Econômica é priorizar negócios com o MERCOSUL. Também se deve ao apoio à política internacional do governo federal. A Caixa atuará principalmente em desenvolvimento urbano e habitacional naquele país. A abertura do escritório manterá a estratégia da Caixa de captar o envio de remessas para o país, mas difere da estratégia dos outros escritórios internacionais do banco porque também visa o comércio exterior, principalmente com o MERCOSUL.

\section{2- Quais os benefícios a abertura do escritório levará para a Venezuela?}

Inicialmente a Venezuela se beneficiará com a cooperação técnica que $\circ$ Brasil tem a oferecer. A Caixa tem muitos conhecimentos em desenvolvimento urbano e esta oferecerá conhecimentos para urbanização das favelas daquele país. A Caixa também oferecerá conhecimentos de bancarização. A Venezuela não conta com o trabalho dos correspondentes bancários e a Caixa trabalha com esses parceiros de uma forma muito avançada. Nosso objetivo é ajudar na implantação desse sistema na Venezuela. 
3- Na sua opinião, o estreitamento das relações entre o governo venezuelano e o governo brasileiro através da implantação do escritório facilitou a aceitação pelo Senado Federal da entrada da Venezuela no Mercosul? Por quê?

A abertura do escritório ajudou, mas não foi o motivo principal. A entrada da Venezuela no MERCOSUL tem mais relação com a ação do governo federal e do Itamaraty. A Caixa é um instrumento do governo, mas a atuação nesse tema foi do Ministério das Relações Exteriores. A Caixa estreita o relacionamento entre os países e só facilitou a conclusão da entrada da Venezuela no MERCOSUL, mas repito: não foi o fator principal.

\section{4- Como você avalia a participação da Venezuela no Mercosul? Isso trará algum benefício ao Brasil?}

A participação da Venezuela é positiva. O MERCOSUL precisa de fatos novos. A Venezuela prioriza a política externa para a América do Sul, assim como o Brasil. Nem todos os países parceiros tem essa prioridade, logo tanto o Brasil quanto a Venezuela tem a lucrar. A política externa da Venezuela é muito aliada à política externa brasileira. A participação da Venezuela no MERCOSUL irá fortalecer a América do Sul.

5- A abertura dos três escritórios internacionais ocorreram no governo do Presidente Lula? Você atribui este fato à política internacional adotada pelo governo?

Sim. Os escritórios internacionais da Caixa começaram a ser abertos em 2003/2004. Primeiramente foi implantado o escritório dos EUA e logo em seguida o do Japão. Em outubro do ano passado (2009) tivemos a abertura oficial do Escritório na Venezuela. Tudo se iniciou de acordo com dois eixos de atuação do governo federal. Primeiramente o objetivo principal era o apoio ao compromisso do governo com os emigrantes brasileiros. A Caixa é um banco popular e os emigrantes do país precisavam de um canal para enviar remessas aos seus familiares que se encontram no Brasil. Como a 
Caixa atinge a faixa da população de baixa renda abertura dos escritórios facilita o envio de numerário a um maior número de clientes e consequentemente atinge uma maior quantidade de cidadãos brasileiros. $O$ segundo eixo foi traçado baseado na política de cooperação técnica do país. Com a implantação do escritório o Brasil passa a contar com mais um instrumento de remessa de valores para o país e não depende mais dos bancos estrangeiros. A Caixa é um banco público e consequentemente muito forte. Muitos países se sentem seguros em realizar negócios com o banco e consentir a abertura do escritório. Atualmente a Caixa reforça a política do governo em incentivar as micro e pequenas empresas. A Caixa tem muitos clientes dessa carteira e o governo tem grande interesse em incentivar o crescimentos dessas empresas. A atuação dessas micro e pequenas empresas é muito crescente no MERCOSUL. A Caixa atualmente também foca o comércio exterior, e isso é totalmente voltado para a política exterior do governo. 